\title{
A Matter of National Security: Whistleblowing in the Military as a Mechanism for International Law Enforcement
}

\author{
DR. ROSLYN FULLER*
}

\section{TABLE OF CONTENTS}

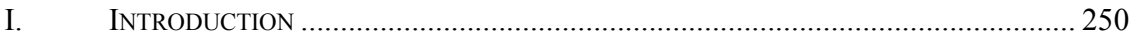

II. The IMPACt OF EXTERnAl WhistLeblowing ON STATE

COMPLIANCE WITH INTERNATIONAL LAW ....

A. Iraq and Afghan War Logs, Cablegate and "Collateral

B. NSA and GCHQ Surveillance Leaks

C. Internal Whistleblowing as an Adequate Alternative?

A Comparison .....

1. Abu Ghraib and the Taguba Report.

2. Internal Whistleblowing as Applied to the Cases of Chelsea Manning, Katharine Gun, and Anat

3. Guja v. Moldova-Internal Whistleblowing "Clearly Impracticable".

III. EXTERNAL WHISTLEBLOWING WITHIN THE FRAMEWORK OF

INTERNATIONAL LAW

A. The Tricky World of International Law ................................................... 271

1. Anat Kamm-Targeted Killings ................................................... 271

2. Katharine Gun-The Second Iraq War ........................................... 277

* C 2014 Dr. Roslyn Fuller. National University of Ireland, Maynooth. My sincere thanks to the editors at the San Diego International Law Journal for their excellent editorial work and helpful comments. All errors are my own. 
3. Chelsea Manning-Cablegate, War Logs and

"Collateral Murder"

B. The Difficulty of Justification in a Dualist System .................................. 285

1. Higher Necessity-Mordechai Vanunu and Ryszard

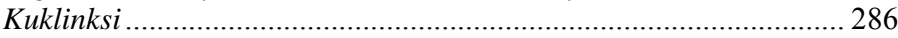

2. Conflict of Duties -Matthew Diaz ................................................. 289

3. Conflict of Duties/Higher Necessity under International

Law_Gun, Kamm and Manning ................................................. 291

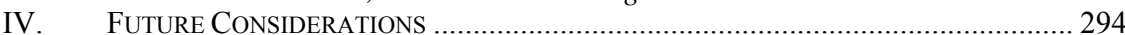

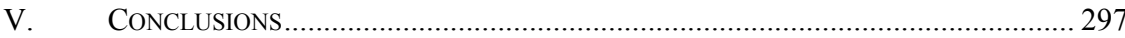

\section{INTRODUCTION}

A whistleblower has variously been described as a person who voluntary discloses an activity that they perceive to be "illegal, unethical or immoral"; "a person who believes that truth should prevail over power" and who, if successful, "brings down corrupt people in high places purely by exposing information", ${ }^{2}$ or a person whose activity "involves "the disclosure by organisation members (former or current) of illegal, immoral, or illegitimate practices under the control of their employers, to persons or organisations that may be able to effect action.",3

As these definitions indicate, there are many kinds of whistleblowerinternal, external, corporate, public - but none are as controversial as the person who reveals the wrongdoing of national security forces by leaking classified material. Such information is, by its very nature, not only sensitive to its proprietary owners, but to the nation as a whole and all of its citizens, especially vis-à-vis their relations with other states. This particular type of whistleblower can therefore be especially interesting to the international law practitioner; in fact, as this paper explores, such whistleblowers have gained considerable relevance for international law in recent years.

Leaking military or intelligence information to external media has a long and varied history, but while earlier defence-industry whistleblowers, such as Daniel Ellsberg ${ }^{4}$ and Mordechai Vanunu, ${ }^{5}$ revealed information

1. Oireachtas Library \& Research Service, Disclosure of Information: Duty to Inform and Whistleblowing, 7 SPOTLIGHT 1, 9 (Dec. 16, 2011).

2. Brian Martin, Illusions of Whistleblower Protection, 5 UTS L. REV. 119, 122

3. Paul Latimer \& AJ Brown, Whistleblower Laws: International Best Practice, 31 U.N.S.W.L.J. 766, 768 (2008) (quoting Janet Near \& Marcia Miceli, Organisational Dissonance: The Case of Whistleblowing, 4 J. Bus. ETHICs 1, 4 (1985).

4. Daniel Ellsberg worked with Anthony Russo, both employees of the partially government-funded security and defence think tank RAND Corporation, to leak topsecret Pentagon Papers to The New York Times in 1971. See George McGovern \& John 
that impacted international relations, they self-identified as being primarily motivated by concerns over constitutionality and the proper exercise of democracy within their respective domestic jurisdictions. ${ }^{6}$ There is, however, reason to believe that this trend is changing and that recent military and intelligence whistleblowers place themselves and their disclosures in a broader global context. While contemporary whistleblowers, such as Chelsea Manning, ${ }^{7}$ Katharine Gun, ${ }^{8}$ and Anat Kamm, ${ }^{9}$ acknowledge motivations similar to those expressed by Ellsberg and Vanunu, they also articulate a desire to expose violations of international law in order

P. Roche, The Pentagon Papers - A Discussion, 87 Pol. ScI. Q. 173 (1972); see also George McT. Kahin, The Pentagon Papers: A Critical Evaluation, 69 AM. Pol. SCI. REV. 675 (1975) (detailing the contents of the papers); THE MOST DANGEROUS MAN IN America: DANiel Ellsberg and THE PENTAGON PAPers (Judith Ehrlich \& Rick Goldsmith 2009) (detailing Ellsberg and Russo's involvement).

5. Mordechai Vanunu, a former employee at the Negev Nuclear Research Center, sold a series of photos that revealed Israel's secret nuclear weapons programme to British newspapers in 1986. See Avigdor Feldman, National Security Secrecy and Mass Destruction Weapons, 9 Comm. LAw 10, 10-13 (1991); Yerech Gover \& Ella Shohat, In Defence of Mordechai Vanunu: Nuclear Threat in the Middle East, 18 Soc. TEXT 95 (Winter 1987-1988) (detailing Vanunu's case).

6. Ellsberg maintained that he had not broken US law, but also eventually stated that his actions were, in any event, justified by necessity, as officials were acting behind a "cloak of secrecy" which "tempted them to ignore the constraints of international or domestic law or the Constitution." See Ellsberg Affidavit at 9, Florida v. Doe, Nos. 87363-MM-A and 87-365-MM-A (Fla. Brevard County Ct. May 20, 1987). Vanunu argued that if Israel "was producing nuclear arms, then concealing this fact from the citizens of the State imposes on them a moral and legal burden which no government has the right to impose on her residents without their knowledge and consent." Feldman, supra note 5, at 11 .

7. Chelsea Manning (formerly known as Bradley Manning), a US Army private, gave hundreds of thousands of military documents subject to various levels of classification, now known, inter alia, as the Iraq War Logs, Afghan War Logs, and US Embassy Cables, to transparency organization Wikileaks for publication in 2010. See Charlie Savage \& Emmarie Huetteman, Manning Sentenced to 35 Years for a Pivotal Leak of US Files, N.Y. TiMES, Aug. 22, 2013, at A1, A14.

8. Katharine Gun, a translator for British intelligence agency GCHQ, leaked an e-mail from the NSA (an American intelligence agency) requesting British help in bugging the communications of UN Security Council members in 2003. See Oliver Burkeman \& Richard Norton-Taylor, The Spy Who Wouldn't Keep a Secret, THE GUARDIAN, Feb. 25, 2004, at G2.

9. Anat Kamm, a former conscript in the Israeli army, leaked hundreds of military documents pertaining to Israel's policy of targeted killing to journalist Uri Blau in 2008. Daniella Peled, The Real Moral of the Anat Kam Story, The GuARDiAn (Apr. 8, 2010, 7:30 AM), http://www.theguardian.com/commentisfree/2010/apr/08/anat-kammshin-bet-israel. 
to prevent such infractions in the future and to prosecute those responsible for past transgressions. These guiding motivations are clearly expressed in statements made by these whistleblowers: Kamm characterized her disclosure of classified documents relating to the Israeli Defence Forces' policy of targeted killings as a measure taken to expose "war crimes"; $;$ " Gun stated that she had tried to prevent "an illegal war" when she leaked the news that the United States and United Kingdom were spying on their fellow UN Security Council members in the run-up to the Second Iraq War; ${ }^{11}$ Manning regarded the embassy cables she passed on to transparency organization Wikileaks as exposing "crazy, almost criminal" activity; ${ }^{12}$ and Edward Snowden has claimed that the US surveillance programmes PRISM and XKeyscore that he revealed to the public infringe, inter alia, on Article 12 of the United Nations Universal Declaration of Human Rights. ${ }^{13}$

These "new" whistleblowers thus, to some extent, perceive themselves as agents for enforcing international law and the question inevitably arises as to whether this self-perception can be justified. Is releasing classified information to the public an effective way to enforce international law? One that is potentially more effective than sharing that information via conventional, non-public whistleblowing legislation? And, if so, what are the implications for both international and national legal systems?

Part II of this article examines the impact that external whistleblowing can have on a state's compliance with international law. Part III looks at some of the complications that disclosing international law violations raises for the broader legal system, in particular, the expertise that a whistleblower

10. Vered Luvitch, Kam: History Forgives Those Who Expose War Crimes, YNETNEws (Apr. 12, 2012, 5:00 PM), http://www.ynetnews.com/articles/0,7340,L3874912,00.html.

11. Ex-GCHQ Officer 'Preventing War', BBC News (Nov. 27, 2003, 1:57 PM), http://news.bbc.co.uk/2/hi/uk news/3243266.stm.

12. Evan Hansen, Manning-Lamo Chat Logs Revealed, WiREd Magazine (July 13, 2011, 3:40 PM), www.wired.com/threatlevel/2011/07/manning-lamo-logs/.

13. The statement was re-printed in a British newspaper. Edward Snowden Statement: 'It was the right thing to do and I have no regrets', THE GUARDIAN (July 12, 2013, 11:15 AM), http://www.theguardian.com/world/2013/jul/12/edward-snowden-fullstatement-moscow. Article 12 of the UN Declaration reads: "No one shall be subjected to arbitrary interference with his privacy, family, home or correspondence, nor to attacks upon his honour and reputation. Everyone has the right to the protection of the law against such interference or attacks." Universal Declaration of Human Rights, G.A. Res. 217 (III) A, art. 12, U.N. Doc. A/RES/217(III) (Dec. 10, 1948). Snowden could also have cited Article 17 of the International Covenant on Civil and Political Rights (ICCPR), which reads "(1) No one shall be subjected to arbitrary or unlawful interference with his privacy, family, home or correspondence, nor to unlawful attacks on his honour and reputation. (2) Everyone has the right to the protection of the law against such interference or attacks." G.A. Res. 2200A(XXI), art. 17, U.N. Doc. A/RES/6316 (Dec. 19, 1966). 
of this type should be expected to have in the area of international law, and judicial reactions to defences related to the exposure of international law violations. Part IV identifies some trends based on this analysis and what they might mean for external whistleblowing on international law violations in the future.

\section{THE IMPACT OF EXTERNAL WHISTLEBLOWING ON STATE COMPLIANCE WITH INTERNATIONAL LAW}

Assessing the impact of external whistleblowing on state behaviour is a complex task. Do states respond when their own violations of international law are publicly revealed, or do they simply ride out any ensuing controversy while maintaining their previous conduct? Moreover, is the public revelation of international law violations more or less effective in inducing corrective behaviour than following internal whistleblowing procedures? Recent cases suggest that states are surprisingly responsive to whistleblowing related to international law infringements and that they often take action to tighten international law compliance. This is particularly evident in the cases of Chelsea Manning and Edward Snowden.

\section{A. Iraq and Afghan War Logs, Cablegate and "Collateral Murder"}

In 2009, Private Chelsea Manning, an American-British citizen deployed with the American Army to Iraq as a junior intelligence analyst, sent hundreds of thousands of internal documents subject to varying levels of security clearance, including the "Collateral Murder" video, ${ }^{14}$ Iraq and Afghan war logs, ${ }^{15}$ and Cablegate documents, ${ }^{16}$ to the transparency

14. Video footage that was taken from the camera of an Apache helicopter gunship shows the helicopter's crew shooting and killing approximately a dozen men in Baghdad in a manner at least partially contrary to the precepts of international humanitarian law. The video was widely distributed on the internet and is available, inter alia, on Wikileaks. See wordswithmeaning, Wikileaks Collateral Murder - Full Gun-cam Raw Footage, YouTUBE (Dec. 3, 2012), http://www.youtube.com/watch?v=78Pk53Xjvtc. For a discussion of the legality of the actions depicted, see infra at 280-83.

15. A collection of army field reports filed during the two conflicts. The reports detail engagements with enemy forces and record, inter alia, the extent of engagement, numerous civilian deaths in questionable circumstances, and a widespread practice of handing over detainees to probable torture at the hands of local police. See Savage \& Huetteman, supra note 7. 
organization Wikileaks with the intention that Wikileaks should make these materials available to the public. ${ }^{17}$ Many of these documents, or their contents, were then published not only online by Wikileaks, but also in print by several major newspapers including The New York Times, Der Spiegel, and The Guardian. While some of the leaked documents do not contain any information of relevance for international law, ${ }^{18}$ there is a general, if not universal, consensus that the Iraq and Afghan war logs, ${ }^{19}$ some of the diplomatic cables, ${ }^{20}$ and the "Collateral Murder" video ${ }^{21}$ all reveal evidence of significant, and in some cases systematic, international law violations committed by state actors.

These disclosures have had a significant international and domestic effect. Not only have they enabled international organizations to monitor the specific international law breaches at issue more closely while cogently and forcefully demanding full compliance with international law, ${ }^{22}$ they

16. Diplomatic cables sent from US embassies to the United States Government. In addition to candid opinions on various heads of state, some cables reveal evidence of probable international law violations.

17. Kevin Poulsen \& Kim Zetter, U.S. Intelligence Analyst Arrested in Wikileaks Video Probe, WiRED (June 6, 2010, 9:31 PM), http:/www.wired.com/threatlevel/2010/ 06/leak/.

18. For example, a 1985 "confidential" cable from the U.S. Embassy in Damascus merely conveyed then-Syrian President Hafez al-Assad's reaction to developments in international relations between Libya and Iraq. Asad Congratulates Qadhafi on Rupture with Iraq, WIKILEAKS (June 27, 1985, 10:29 AM), https://wikileaks.org/cable/1985/ 06/85DAMASCUS4001.html.

19. For details and statements, see David Batty \& Jamie Doward, Iraq War Logs: UN Calls on Obama to Investigate Human Rights Abuses, THE GuARDIAN (Oct. 23, 2010, 8:41 AM), http://www.theguardian.com/world/2010/oct/23/united-nations-callobama-investigation-abuses-iraq.

20. In one cable, Papua New Guinea's Consul alleges that the Indonesian Armed Forces are involved in illegal logging and drug smuggling in Papua New Guinea. The Two Papuas: A Consul General's View, WiKILEAKS (Oct. 20, 2006, 12:24 PM), https://www.wikileaks.org/plusd/cables/06JAKARTA12783_a.html. Two other cables, both labelled "secret," suggest the complicity of Sri Lankan government officials in numerous violations of international humanitarian law. See Sri Lanka War Crimes Accountability: The Tamil Perspective, WiKILEAKS (Jan. 15, 2010, 12:23 PM), http:// wikileaks.org/cable/2010/01/10COLOMBO32.html; Sri Lanka: GSL Complicit in Paramilitary Factions’ Human Right Abuses, WiKILEAKs (May 18, 2007, 9:22 AM), https://www.wikileaks.org/plusd/cables/07COLOMBO728 a.html.

21. See discussion infra at 280-83.

22. UN Special Rapporteur on Torture, Manfred Nowak, has called on the United States Government to comply with its obligations under the Convention Against Torture, to investigate the abuses revealed by the war logs, to try all those who are responsible for torture in Iraq, either directly or through complicity, and to compensate victims. Batty \& Doward, supra note 19. UN High Commissioner for Human Rights, Navi Pillay, explicitly referenced the documents disclosed by Wikileaks when urging investigation and trial of those responsible "in line with obligations under international human rights law, including the International Covenant on Civil and Political Rights to which both the 
have also prompted internal action within certain states with a view to either punishing the individuals responsible for infringements or bringing their conduct back into compliance with international law and avoiding future violations.

Following the release of the Iraq and Afghan war logs, the Danish government announced that it will "set up a commission of inquiry to shed light on ... potential problems relating to Denmark's observance of international conventions in connection with warfare in Iraq and Afghanistan." ${ }^{23}$ Danish authorities also indicated that they may pursue individuals held to have violated international law in relation to these conflicts. ${ }^{24}$ The United Kingdom's Deputy Prime Minister, Nick Clegg, has taken a similar position vis-à-vis the international law violations revealed by Private Manning, stating, "I think anything that suggests that basic rules of war, conflict and engagement have been broken or that torture has been in any way condoned are extremely serious and need to be looked at." $" 25$ These officials - both Danish and British - make the point that a primary motivation in advocating action is to bring their nations into compliance with international law and to pursue those responsible for international law violations.

Shortly after Clegg stated his position, the Iraq Historic Allegations Team (IHAT) started to investigate allegations of torture committed by British armed service members and government employees in Iraq. ${ }^{26}$ Although IHAT had been contemplated since March $2010^{27}$ (i.e. some months before the war logs were released), given the time at which it commenced operations, the leaks may have added some impetus to, and

US and Iraq are parties." Iraq/Wikileaks: Statement by the Office of the UN High Commissioner for Human Rights, United Nations Human Rights (Oct. 26, 2010), http://www.ohchr.org/EN/NewsEvents/Pages/DisplayNews.aspx?NewsID=10477\&Lang $\mathrm{ID}=\mathrm{E}$.

23. Peter Stanners, Iraq Commission to Investigate Danish Involvement in War, The Copenhagen Post (Apr. 12, 2012, 12:06 PM), http://cphpost.dk/news/iraqcommission-to-investigate-danish-involvement-in-war.1258.html. In particular, Danish forces are alleged to have handed over prisoners to local authorities despite knowing that they would likely be tortured. Id.

24. Id.

25. Richard Spencer, Wikileaks: Nick Clegg Backs Call for Investigation, THE TELEGRAPH (Oct. 24, 2010, 5:55 PM), http://www.telegraph.co.uk/news/worldnews/ middleeast/iraq/8084116/Wikileaks-Nick-Clegg-backs-calls-for-investigation.html.

26. Ministry of Defence, Iraq Historic Allegations Team Starts Work, GOV.UK (Nov. 1, 2010), https://www.gov.uk/government/news/iraq-historic-allegations-team-starts-work.

27. See Mousa v Sec'y of State for Def. [2011] EWCA (Civ) 133 (Eng.), ๆ 14. 
certainly added increased public awareness of, its operations. Previously, investigations of international law breaches committed by British forces in Iraq had occurred only on a limited basis in the contexts of the alSweady Inquiry, which focused on the particular incident of the Battle of Danny Boy, ${ }^{28}$ and the Baha Mousa Inquiry, which focused on the death of Baha Mousa and "those detained with him" by British forces in Basra, Iraq. ${ }^{29}$ Although the Baha Mousa Inquiry resulted in voluminous recommendations for general reform (seventy-three in total) within the British Armed Forces, as far as culpability was concerned, the Inquiry was naturally limited to the specific incidents that it had been tasked to investigate, ${ }^{30}$ circumstances which the British government still viewed as "extremely rare." 31 Disturbingly, judges complained of being able to convict only one person for Mousa's death due to the armed forces' "closing of ranks." ${ }^{32}$ IHAT plans to reinvestigate Mousa's death as well as over a thousand other allegations. ${ }^{33}$ Thanks in part to Manning's disclosures, it is doing so in an atmosphere of heightened public scrutiny.

This, in turn, can help to ensure IHAT's effectiveness in accurately assessing the nature and extent of international law violations while minimizing opportunities for corruption or incompetence to affect outcomes. British courts have ordered alterations to IHAT practices to ensure independence, citing, in part, the importance of public perception and the need for justice to be seen to be done. ${ }^{34}$

Where courts enjoy independence from executive bodies, domestic judicial decisions can also provide an extremely powerful method of

28. This inquiry is still ongoing, for more information, see Richard Norton-Taylor, AlSweady Inquiry into Iraq War Abuse Allegations to Hear from Commander, THE GUARDIAN (Jan. 6, 2014, 10:39 AM), http://www.theguardian.com/uk-news/2014/jan/06/ al-sweady-inquiry-evidence-commander-andrew-kennett. See also AL-SwEADY PUBLIC INQUIRY, http://www.alsweadyinquiry.org/index.htm (last visited Mar. 14, 2014).

29. See Frequently Asked Questions, THE BAHA MOUSA INQUIRY, http://www. bahamousainquiry.org/faqs may09.htm (last visited Mar. 14, 2014).

30. Sir William GAGe, The Report of the BAHA Mousa InQuiry (2011), available at http://www.bahamousainquiry.org/report/index.htm.

31. Liam Fox, Secretary of State for Defence, Statement on the Report into the Death of Mr. Baha Mousa in Iraq in 2003 (Sept. 8, 2011), available at https://www. gov.uk/government/speeches/2011-09-08-statement-on-the-report-into-the-death-of-mr-bahamousa-in-iraq-in-2003.

32. Ben Knight, Abuse in UK's Iraq Occupation was 'Systemic', DeUTSCHE WeLlE (Jan. 24, 2013), http://www.dw.de/abuse-in-uks-iraq-occupation-was-systemic/a16541688 (quoting Justice Ronald McKinnon).

33. See Iraq Historic Allegations Team (IHAT), Gov.UK (last visited, Mar. 17, 2014), https://www.gov.uk/government/policy-teams/iraq-historic-allegations-team-ihat

34. See Mousa, supra note $27, \mathbb{9} 35$. 
international law enforcement, ${ }^{35}$ but they can only operate effectively where pertinent information and evidence are available to those parties with grounds to initiate a case. By releasing information to the public, external whistleblowers ensure that groups and individuals can take action on a domestic level in those instances where domestic norms give effect to, or coincide with, the norms of international law. To give one particularly long-running example: Public Interest Lawyers, which represents victims of alleged abuse in Iraq, claims that the Iraq war logs document the extent to which American - and therefore also Britishpersonnel were aware of the widespread and serious mistreatment of Iraqi prisoners by British, American, and Iraqi forces. ${ }^{36}$ Despite their apparent knowledge of the particularly widespread and severe abuses perpetrated by Iraqi authorities, Britain had continued to transfer prisoners to Iraqi custody in violation of the principle of non-refoulement. ${ }^{37}$ This information, which had not been available to Public Interest Lawyers or their clients prior to Wikileaks' release of the Iraq war $\operatorname{logs},{ }^{38}$ has bolstered its contention that officials and military superiors culpably failed to prevent abuse in Iraq, and thus enhanced the law firm's efforts to bring a new judicial review advocating a full public inquiry "into all breaches of the duty of non-refoulement by handing over Iraqis to the Iraqi authorities." 39

\section{B. NSA and GCHQ Surveillance Leaks}

In 2013, National Security Agency (NSA) analyst Edward Snowden publicly revealed the existence of the NSA and Government Communication Headquarters (GCHQ) mass surveillance programmes PRISM, XKeyscore, and Tempora. The documents leaked by Snowden detail a range of covert

35. For one aspect of international law enforcement through domestic judicial decisions, see Sandeep Gopalan \& Roslyn Fuller, Enforcing International Law: States, IOs, and Courts as Shaming Reference Groups, 39 BROOK. J. INT'L L. 73 (2014).

36. Mazin Younis, New Legal Challenge over Iraq War Logs: Iraqi Torture Case, PUBLIC INTEREST LAWYERS, http://www.publicinterestlawyers.co.uk/news_details.php? id=13 (last visited Mar. 14, 2014).

37. Id.

38. Id

39. Id. See also Batty \& Doward, supra note 19. This has further developed into a request (submitted by Public Interest Lawyers and the European Centre for Constitutional and Human Rights) for the International Criminal Court's prosecutor to investigate British war crimes in Iraq, although the precise relation between the information contained in the Iraq war logs and this second action is unclear. Sam Jones, Lawyers Call for Prosecutions over Iraq Abuse, FinANCIAL TIMES, Jan. 122014. 
surveillance activity, including: numerous hacks into the communications of foreign heads of state, often conducted from US or allied embassies; ${ }^{40}$ the mass, warrantless surveillance of millions of private citizens; ${ }^{41}$ and bugging operations conducted within international organizations and the premises of foreign representations. ${ }^{42}$ These actions constitute violations of Article 17 of the International Covenant on Civil and Political Rights, ${ }^{43}$ the sovereignty of the affected states, and, in some cases, the Vienna Convention on Diplomatic Relations. ${ }^{44}$ Despite their obvious illegality, these breaches were conducted over a lengthy period of time without becoming subject to internal corrective action. Since the breaches have become public, this situation has changed dramatically.

40. These actions included hacking the President of Mexico's e-mail account and tapping into German Chancellor Angela Merkel's cell phone from the US Embassy in Berlin. See Jens Glüsing, Laura Poitras, Marcel Rosenbach \& Holger Stark, Fresh Leak on US Spying: NSA Accessed Mexican President's E-mail, DeR SPIEGEL, Oct. 21, 2013; NSA Überwachung: US-Senat will Handy-Affäre untersuchen [NSA Surveillance: U.S. Senate will Examine Mobile Affair], SPIEGEL ONLINE (Oct. 28, 2013), http://www.spiegel. de/politik/ausland/nsa-und-merkel-us-senat-plant-untersuchung-der-handy-affaere-a-930524. html; Der unheimliche Freund [The Uncanny Friend], DER SPIEGEL, Oct. 28, 2013, at 20.

41. The NSA intercepted over 60 million phone calls in the span of just one month in Spain alone. Spain Launches Legal Inquiry into U.S. Spying Allegations, EURO WEEKLY NEws (Oct. 29, 2013, 4:39 PM), http://www.euroweeklynews.com/news/spain/ item/116777-spain-launches-legal-inquiry-into-us-spying-allegations. See also Julian Borger, GCHQ and European Spy Agencies Worked Together on Mass Surveillance, The Guardian, Nov. 1, 2013; Philip Bump, The UK Tempora Program Captures Vast Amounts of Data - and Shares with NSA, THE WIRE (June, 21 2013, 2:22 PM), http://www.theatlanticwire.com/national/2013/06/uk-tempora-program/66490/; Kadhim Shubber, A Simple Guide to GCHQ's Internet Surveillance Programme Tempora, WIRED.CO.UK (June 24, 2013), http://www.wired.co.uk/news/archive/2013-06/24/gchqtempora-101; Evan MacAskill, Julian Borger, Nick Hopkins, Nick Davies \& James Ball, GCHQ Taps Fiber-Optic Cables for Secret Access to World's Communications, THE GUARDIAN, June 21, 2013.

42. The NSA bugged the European Union diplomatic representations in Washington and New York, thereby gaining access to e-mail and internal documents, and tapped the UN's internal communication network, thus spying not only on UN officials, but also country delegations. See Holger Stark, Spähaffäre: Einsames Amerika, SPIEGEL ONLINE (Oct. 28, 2013, 4:11 PM), http://www.spiegel.de/politik/ausland/kommentar-nsa-willwie-obama-ueber-den-dingen-stehen-a-930337.html; Marcel Rosenbach \& Holger Stark, Codename 'Apalachee': How America Spies on Europe and the UN, DER SPIEGEL, Aug. 26, 2013.

43. Article 17 of the ICCPR protects individuals against arbitrary or unlawful interference with privacy, the family, the home, and correspondence. G.A. Res. 2200A(XXI), art. 17, U.N. Doc. A/RES/6316 (Dec. 19, 1966).

44. Articles 22, 24, and 27(2) of the VCDR, in particular, protect the premises and communications of the diplomatic mission, which are violated when the mission is bugged by another state's organs. Vienna Convention on Diplomatic Relations arts. 22, 24, 27 ๆ 2, Apr. 18, 1961, 500 U.N.T.S. 95. 
A major coalition partner within the German Government, the Social Democrats (SPD), has demanded that the Bundestag investigate the evidence released by Snowden, ${ }^{45}$ while Spain's public prosecutor launched a preliminary inquiry after news emerged that the NSA had intercepted over 60 million phone calls in Spain over the course of just one month. ${ }^{46}$ The European Parliament has voted in favour of investigating the surveillance activities of the United States on European citizens and has condemned NSA spying on its representations. ${ }^{47}$ Moreover, in Mexico a legislative commission has called for internal investigation into the nation's standards of data protection, ${ }^{48}$ while Brazil has been prompted to change its data protection laws. ${ }^{49}$ Upon the initiative of Germany and Brazil,${ }^{50}$ the UN General Assembly passed a resolution aimed at protecting privacy in the digital age on December $18,2013 .^{51}$ Although the wording of the resolution omitted the original intent that mass surveillance explicitly be characterized as a human rights violation, it does clarify that the idea of privacy is not obsolete in the digital age and that, to the contrary, citizens continue to enjoy the same privacy rights online as they do offline. ${ }^{52}$

Action has also been taken in the United States itself: the Senate has announced its intention to launch an investigation of all secret service

45. Spähaffäre: SPD fordert NSA-Untersuchungsausschuss, SPIEGEL ONLINE (Oct. 27, 2013, 12:01 AM), http://www.spiegel.de/politik/deutschland/spaehaffaere-oppermannfordert-nsa-untersuchungsausschuss-a-930222.html.

46. Spain Launches Legal Inquiry into U.S. Spying Allegations, supra note 41

47. Press Release, European Parliament, Parliament to Launch In-Depth Inquiry into US Surveillance Programmes (July 8, 2013), available at http://www.europarl.europa. $\mathrm{eu} /$ news/en/news-room/content/20130701IPR14770/html/Parliament-to-launch-in-depthinquiry-into-US-surveillance-programmes.

48. Segunda Comisíon: Relaciones Exteriores, DefENSA Nacional y EduCaCíon Pública, Dictamen Con Punto de ACuerdo Que Exhorta a Diversas DePEndencias DE la Administración PÚblica Federal a Rendir un InForme Sobre El Uso del SOFTWARE PARA ESPIONAJE "FINFISHER" EN ACTIVIDADES DE RECOLECCIÓN DE INTELIGENCIA (2013), available at http://sil.gobernacion.gob.mx/Archivos/Documentos/ 2013/07/asun_ 2992645_20130731_1375375137.pdf.

49. Glüsing et al., supra note 40.

50. Anja Fähnle, Germany and Brazil Want UN Vote on NSA Spying, DeUTSCHE WeLLE (Oct. 30, 2013), http://www.dw.de/germany-and-brazil-want-un-vote-on-nsa-spying/ a-17193657.

51. G.A. Res. 68/167, U.N. Doc. A/RES/68/167 (Dec. 18, 2013).

52. See Edith M. Lederer, UN Votes to Protect Privacy in Digital Age, SydneY MorNING HerAld (Dec. 19, 2013), http://www.smh.com.au/it-pro/security-it/un-votesto-protect-privacy-in-digital-age-20131219-hv6h5.html. 
programmes, ${ }^{53}$ while the government is considering allowing amicus curiae to be filed at the Foreign Intelligence Surveillance Court $^{54}$ and creating an independent review panel-steps intended to halt more intensive surveillance on private persons where there are not sufficient grounds to believe they pose a threat to national security. ${ }^{55}$ President Barack Obama has also ordered NSA spying at the UN, International Monetary Fund (IMF), and World Bank to be curtailed or halted, despite the fact that spying operations at those institutions-presumably of the offices of national representatives - had not been made public. ${ }^{56}$ This indicates that such leaks can prompt pre-emptive compliance as states fear the consequences of as-yet-undiscovered violations. Perhaps most significantly, Snowden's revelations have enabled citizens in the United States to bring lawsuits against government officials and telecommunications companies implicated in conducting mass surveillance on American citizens residing in the United States. ${ }^{57}$

The information revealed by Edward Snowden has prompted both modest corrective behaviour on the part of the United States that is particularly focused on bringing itself back into compliance with international law in the form of the Vienna Convention on Diplomatic Relations, as well as robust action on the part of other states to prevent such violations against their own citizens in future. Thus, even if the perpetrator state is unwilling to substantially alter its conduct, norms of international law can be enforced by enabling other states to take protective action on the basis of the leaked information. This also holds true when those states have previously been complicit in violations against their own citizens. States are not monolithic entities and international law violations may be perpetrated by a small group of individuals or state organs, especially where appropriate oversight is lacking. In these

53. NSA Überwachung: US-Senat Will Handy-Affäre Untersuchen, supra note 40.

54. Christi Parsons \& Ken Dilanian, Obama calls for Changes to Patriot Act, Los ANGELES Times (Aug. 9, 2013), http://articles.latimes.com/2013/aug/09/news/la-pnobama-patriot-act-oversight-20130809.

55. Obama Pledges Surveillance Changes, THE IRISH INDEPENDENT (Aug. 9, 2013), http://www.independent.ie/world-news/obama-pledges-surveillance-changes-29487228.html; Barack Obama Pledges Changes to Restore Trust in NSA Surveillance Programs, ABC News (Aug. 10, 2010, 6:44 AM), http://www.abc.net.au/news/2013-08-10/obama-pledgeschanges-to-restore-trust-in-nsa-spying/4877886.

56. Mark Hosenball, Obama Halted NSA Spying on IMF and World Bank Headquarters, REUTERS (Oct. 31, 2013, 6:49 PM), http://www.reuters.com/article/2013/10/ 31/us-usa-security-imf-idUSBRE99U1EQ20131031.

57. Klayman v Obama, No. 13-0881, 2013 U.S. Dist. LEXIS 176925 (D.D.C. Dec. $16,2013)$ 
cases, revealing this complicity may enable other state organs to take corrective action. ${ }^{58}$

Of course, not all cases of external whistleblowing result in such clearcut repercussions - the precise impact of the information revealed by Katharine Gun or Anat Kamm remains, by its very nature, more difficult to assess. This difficulty, however, is symptomatic of most methods of law enforcement and does not negate the fact that external whistleblowing can play an important role in encouraging international law compliance, if not necessarily producing quantitatively measurable results in every instance. Furthermore, the identity of the states concerned is also a factor in responsiveness to all forms of whistleblowing. Some states and governments may be more sensitive to allegations of international law violations and more willing to investigate and take corrective action, while other states may show more resistance under the same or similar circumstances. The point remains that external whistleblowing can increase the level of state commitment to enforcing international law to the benefit of those affected by the violations in a direct and traceable fashion as demonstrated by the above examples.

\section{Internal Whistleblowing as an Adequate Alternative? A Comparison}

Going public with evidence of international law violations would seem to be effective in aiding compliance in certain cases, but is it necessary? This is a worthy point because security leaks, i.e., precisely those leaks that tend to have the most relevance for international law, inherently risk jeopardizing a state's internal security and it is therefore unlikely that many states would wish to unconditionally endorse it as a method of enforcing international law. Moreover, military and intelligence personnel who witness breaches of international law often have the option of internal whistleblowing, i.e., communicating their concerns to superiors or internal agencies, and in some jurisdictions even to external bodies. ${ }^{59}$

58. Borger, supra note 41. (revealing a level of cooperation between the intelligence services of a number of Western European countries in the mass, warrantless surveillance of their own citizens).

59. U.S. Military Whistleblower Protection Act, 10 U.S.C. § 1034(a)(1) (1988) (stating that no one "may restrict a member of the armed forces in communicating with a Member of Congress or an Inspector General" provided the communication is lawful; $\S 1034(b)$ prohibits reprisals). 
Utilizing internal whistleblowing procedures ensures that any accusation that could compromise state security does not lead to irreparable damages to that state's international relations or defence policy. In the ideal scenario, the whistleblower is able to "enforce" through these internal mechanisms and therefore has no need to reveal information to the public, an action which could potentially entail hazardous consequences. However, it is wellknown that there are many reasons for whistleblowers to prefer external disclosure, such as a lack of confidence in internal procedures, urgency, or fear of reprisals, ${ }^{60}$ such as harassment or ostracism. ${ }^{61}$ Others go further, arguing that the "official channels" serve as little more than a mechanism for deflating the impact of whistleblower activity because "whistleblowers are a potential threat to nearly everyone in powerful positions and thus need to be domesticated. .. . Given that the procedures involved may take months or years while the problem remains unchallenged, this provides a perfect method to minimize challenges to organizational hierarchies." 62

Regardless of the truth this may have for domestic whistleblower protection, it certainly resonates for the majority of international law violations, especially those which occur within the secrecy-cloaked context of military and intelligence operations. Due to the hierarchical nature and vertical structure of military and defence organizations, in many cases the potential whistleblower's superiors will have prior knowledge of the activities concerned. This is especially the case when the violations are pervasive. In such circumstances, even reporting to parliamentary bodies (as foreseen in the US Military Whistleblower Protection Act of $1988)^{63}$ may prove futile, as it may not be politic for parliamentarians to question the tactics used in a conflict which they themselves have authorized, or those who are willing to question such tactics may lack the clout to take effective action. ${ }^{64}$ Furthermore, it cannot be excluded that international law violations committed repeatedly and with impunity by the agents of a state form part of that state's official or unofficial policy. In such a situation it is unrealistic to expect that state's whistleblowing laws to operate in optimal fashion and lead, by themselves, to long-lasting correction

60. See Latimer \& Brown, supra note 3, at 777.

61. Martin, supra note 2, at 119 (writing in the context of civilian whistleblowing).

62. Id. at $122-23$

63. 10 U.S.C. $\$ 1034$ (1988).

64. This was made particularly obvious in the case of Daniel Ellsberg. Ellsberg successfully delivered the Pentagon Papers to a number of US Senators, but this did not result in effective action. Susan Gardner, Conversations with Daniel Ellsberg, Part 1, DAILY Kos (Jan. 20, 2006, 2:53 PM), http://www.dailykos.com/story/2006/01/20/ 179996/-Conversations-with-Daniel-Ellsberg-Part-1); see also Guja v. Moldova, 2008-II Eur. Ct. H.R., available at http://hudoc.echr.coe.int/sites/eng/pages/search.aspx?i=00185016 (acknowledging that even whistleblowing to Parliament might prove ineffective). 
of international law infringements. While, by their very nature, cases of internal whistleblowing are non-public and therefore difficult to systematically assess, the example of the Abu Ghraib prisoner abuse scandal is illustrative in this context.

\section{Abu Ghraib and the Taguba Report}

In early 2004, Sergeant Joe Darby was stationed at Abu Ghraib prison in Iraq when a fellow soldier handed him a CD containing, inter alia, images of Iraqi prisoners being humiliated and severely abused by soldiers stationed at the prison contrary to international human rights and international humanitarian law. ${ }^{65}$

Unlike the other whistleblowers examined in this paper, Darby does not seem to have considered the actions depicted in these photos in terms of international law violations (although many of them undoubtedly are) ${ }^{66}$ instead, he described the content of the photos as simply 'not sitting right' with him. ${ }^{67}$ Shortly after receiving the photographs, Darby turned

65. Although some of the photos have been widely circulated publicly, those depicting the most severe forms of abuse are rarely, if ever, shown, due to their graphic and disturbing nature. Seymour M. Hersh, The General's Report, THE NEW YORKER (June 25, 2007), http://www.newyorker.com/reporting/2007/06/25/070625fa_fact_hersh.

66. For example, forcing detainees to perform sexual acts, rape, beatings, enforced stressed positions, and even killing detainees. Jane Mayer, A Deadly Interrogation, THE NEW YORKER (Nov. 14, 2005), http://www.newyorker.com/archive/2005/11/14/051114fa fact? currentPage $=1$. These actions were committed by US military and intelligence forces and contravene both international human rights and international humanitarian law. Seymour M. Hersh, Torture at Abu Ghraib, THE NEW YORKER (May 10, 2004), http://www. newyorker.com/archive/2004/05/10/040510fa fact?currentPage=1); see also MAJ. GEN. Antonio Taguba, Article 15-6 Investigation of the 800Th Military Police BRIGADE (2004), available at http://news.findlaw.com/hdocs/docs/iraq/tagubarpt.html\#ThR1.13.

67. Darby's exact words were: "The ones of prisoners being beaten, or the one with a naked Iraqi sitting on his knees in front of another naked Iraqi, some of the more sexually-explicit-type stuff to humiliate the prisoners - it just didn't sit right with me." Wil S. Hylton, Prisoner of Conscience, GQ MAGAzINE, Sept. 2006. He continued: "I've kept a lot of secrets for soldiers. In the heat of the moment, in a war, things happen. You do things you regret. I have exceeded the proper use of force myself a couple of times. But this crossed the line to me." Id. This illustrates the difficulty that accurately assessing international law presents for the non-practitioner. Darby revealed what are unquestionably violations of international law (the Third and Fourth Geneva Conventions explicitly concern themselves with the protection of prisoners in conflict situations, while Art. 6 ICCPR protects the right to life and Art. 7 ICCPR prohibits torture, as well as cruel, inhuman, or degrading treatment, as does the Convention Against Torture). Nonetheless, Darby apparently did not even consider international law as a motivation for reporting his colleagues. This difficulty is discussed more thoroughly below. 
them over to the Army's Criminal Investigation Division (CID) ${ }^{68}$ The CID's initial actions were promising; those responsible for the abuse were immediately rounded up as Darby identified them. ${ }^{69}$ Moreover, when then-Secretary of Defense Donald Rumsfeld revealed Darby's identity as the whistleblower during a Congressional hearing several months later, the Army quickly transported Darby back to the United States in order to prevent reprisals. ${ }^{70}$

However, despite these positive actions, the episode reveals cause for serious concern regarding the ability of internal whistleblowing procedures to adequately combat systemic or widespread international law infringements. As might be expected, the evidence supplied by Darby prompted an internal investigation, responsibility for which was assigned to Major General Antonio Taguba. The Major General completed a report in March 2004, but later raised accusations that there had been many irregularities, both in the manner in which the investigation was conducted and in which his report was received. In Taguba's opinion, the troops at Abu Ghraib prison were not acting on their own initiative and he was prevented from investigating their military superiors, although it was "standard operating procedure to assume that this had to go higher." "In this opinion, Taguba was joined by the CID, which also complained of having investigations into prisoner abuse thwarted. ${ }^{72}$ Taguba's suspicion that the severe mistreatment experienced by detainees at Abu Ghraib prison formed part of a wider policy was partially grounded in the fact that intelligence agencies (in particular the CIA) were involved in the abuse. ${ }^{73}$ How could those higher up the chain of command be unaware of the situation in Abu Ghraib prison, Taguba questioned, when the intelligence agencies were taking advantage of it to engage in irregular practices with regards to prisoner interrogation? ${ }^{74}$ Darby had even disclosed at least one incident of intelligence personnel killing a prisoner whose corpse was depicted in the photographs released. ${ }^{75}$

68. Id.

69. Id.

70. Id.; Anjani Trivedi, What's Next for Snowden: 10 Notorious Leakers and How They Fared, Time World MAGAZINE (June 10, 2013), http://world.time.com/2013/06/10/10notorious-leakers-and-how-they-fared/slide/abu-ghraib-photo-leak/.

71. Hersh, The General's Report, supra note 65.

72. Id.

73. Hersh, The General's Report, supra note 65; Hersh, Torture at Abu Ghraib, supra note 66.

74. Hersh, The General's Report, supra note 65.

75. These photos were among those turned over by Darby. Hylton, supra note 67. 
Taguba also claimed that his investigation was not taken seriously by those in the highest echelons of power. ${ }^{76}$ Although Darby turned in the photographs in January and Taguba completed his report in March, Congressional hearings were not held until May 2004, shortly after the photographs and the report were leaked to the press. ${ }^{77}$ Taguba claimed that at a conference held with Rumsfeld the day before the then-Secretary of Defense testified at the Congressional hearings, Rumsfeld stated that he had neither read Taguba's report nor viewed the photographs, despite the fact that both were now widely available via popular media and had been previously transmitted to the Pentagon ${ }^{78}$ In fact, the Department of Defense had already successfully induced the media, in the form of the news channel CBS, to delay airing the photographs for two weeks after they were leaked. ${ }^{79}$ In light of these facts, it is unsurprising that the evidence disclosed by Darby has been described as "languish[ing] at relatively low levels in the chain of command" before it was leaked to the public. ${ }^{80}$ It is noteworthy that prior to Darby's actions, the International Committee of the Red Cross had visited Abu Ghraib prison twice, documenting and reporting to the commanding officer, Brigadier-General Janis Karpinski, "the use of sleep deprivation, forced nudity, shackling, sensory bombardment, and stress positions." ${ }^{11}$ These reports did not lead to any effective action being taken to halt the torture and abuse. ${ }^{82}$ The handling of the Abu Ghraib prisoner abuse would thus seem to illustrate that "nothing will lead to a response as effectively as the whistleblower going public through making a disclosure to the media" since top-level action was only taken when the photographs became publicly available, following - if Taguba's assertions are correct - an apparent history of obstruction and feigned ignorance.

76. Taguba provided anonymous statements to New Yorker reporter Seymour Hersh, such as, "I don't want to get involved by looking [at the photographs provided by Darby]," as well as what he felt were mocking comments that he had personally received from high-level officials, Hersh, The General's Report, supra note 65.

77. See id. (detailing Rumsfeld's numerous complaints about the report having already leaked to the press before and during the Congressional hearings).

78. Id. (showing that Rumsfeld later repeated this claim of ignorance during the Congressional hearings on May 7, 2004).

79. Jared Del Rosso, The Textual Mediation of Denial: Congress, Abu Ghraib, and the Construction of an Isolated Incident, 58 Soc. ProBs. 165, 172 (May 2011).

80. Id. at 172 .

81. Id. at $171-72$.

82. Id.

83. Latimer \& Brown, supra note 3, at 781. 
Once the information was in the public realm, the possibility that prisoner abuse in Iraq was not limited to a small, "rogue" group of low-ranking soldiers was raised at several points in the ensuing congressional hearings, ${ }^{84}$ and the Senate Armed Services Committee conducted the Inquiry into the Treatment of Detainees in US Custody. ${ }^{85}$ This inquiry pinned ultimate responsibility for the abuse on superior officers, including finding that Rumsfeld, as Secretary of Defense, had created an atmosphere in which soldiers were encouraged to act in overly aggressive and abusive ways to detainees, as evidenced by the so-called Torture Memos. ${ }^{86}$

The case of Abu Ghraib thus closely parallels British investigations into allegations of torture and other forms of mistreatment in Iraq as exhibited by the inquiries discussed above. As with the British cases, despite evidence of systematic international law breaches by US armed forces, a thorough investigation only got off the ground once the evidence was leaked to the public. Previously, allegations and evidence such as that brought forward by Darby were treated on a piecemeal basis which was inadequate to deal with the severity of the situation and which permitted the majority of perpetrators to act with impunity. This reinforces the point that internal whistleblowing may work well for coping with isolated international law breaches, but not for effectively combatting the widespread or systematic abuse that is condoned by those in positions of power. Internal whistleblower legislation, in other words, fails at precisely those times when it is most desperately needed.

\section{Internal Whistleblowing as Applied to the Cases of Chelsea Manning, Katharine Gun, and Anat Kamm}

Chelsea Manning's case points to even more serious internal failures in military whistleblowing procedure. At the time that Manning leaked the "Collateral Murder" video to Wikileaks, the military legal review of the incident had long been closed. In fact, it had been concluded just five days after the incident took place, and there were no plans to re-investigate when the video was leaked nearly three years later. ${ }^{87}$

84. Del Rosso, supra note 79, at 176-77.

85. Senate Armed Services Committee, Inquiry into the Treatment of Detainees in US Custody, Executive Summary, at xxviii (May 10, 2007) (unpublished executive summary), available at http://www.levin.senate.gov/download/?id=adc98e54-ae7d-4675-95bd-83eaaf42 0268 .

86. See id. at Conclusion 13.

87. US Military 'Cannot Find Iraq Tape’, AL JAZEERA (Apr. 8, 2010, 10:03 AM), http://www.aljazeera.com/news/americas/2010/04/20104814952153608.html. Some sources indicate that two military investigations were conducted, but that both led to the same result, the conclusion that the gunship's pilots had acted correctly. Video Shows 'US Attack' 
The video footage, commonly termed "Collateral Murder" after the title assigned to it by Wikileaks, shows nearly a dozen men, including two journalists, being fired upon and killed by an Apache helicopter under questionable provocation. ${ }^{88}$ The video then records the gunship's crew firing on the driver of a van and two bystanders as they attempt to load a reporter who had been wounded in the initial attack into the vehicle. ${ }^{89}$ The driver of the vehicle, and possibly the two bystanders, were killed and the driver's two children, occupants of the van, were seriously injured in this attack. ${ }^{90}$ The military report nevertheless justified the use of lethal force without warning on non-combatant minors and persons attempting to aid an individual who was, at the very least, hors de combat, on the grounds that "the Apache pilots thought the van was to be used as a means of escape for the wounded insurgents." 91 The report stated, almost immediately thereafter, "[i]t is unknown what, if any, connection the van had to insurgent activity." 92 No disciplinary action had been taken against the pilots at the time the video leaked, nearly three years after the shooting. ${ }^{93}$ The internal review mechanisms in place had thus already failed to make a cohesive and convincing determination of accountability for the incident, which amounted, at least in part, to a war crime,${ }^{94}$ or to take effective action to prevent its reoccurrence. ${ }^{95}$

on Iraqis, AL JAZEERA (Apr. 6, 2010, 3:10 AM), http://www.aljazeera.com/news/americas/ 2010/04/201045123449200569.html.

88. For details, see infra at 280-83.

89. See minute 6:15-9:01 in the unedited footage from the gunship's camera. See wordswithmeaning, supra note 14; see also Tim Arango \& Elisabeth Bumiller, For 2 Grieving Families, Video Reveals Grim Truth, N.Y. TimeS, April 7, 2010, A8 (confirming the identity of the wounded man seen in the video as reporter Saeed Chmagh).

90. See US soldier on Aftermath of Wikileaks Apache Attack, BBC News (Oct. 28, 2010, 7:10 PM), http://www.webcitation.org/5yGAVeN6S (containing excerpts from interview with Ethan McCord, the U.S. soldier who evacuated the children from the van after the attack); see also Families of Victims of 2007 US Helicopter Killing React to Leaked Video, DEMOCRACY Now (Apr. 12, 2010), http://www.democracynow.org/2010/4/12/ families_of_victims_of_2007_us (confirming that the children in the vehicle were the driver's own children in interviews with the driver's surviving family members).

91. Memorandum for Commander, 2d Infantry Brigade Combat Team, 2d Infantry Division (MND-B) on Investigation of Civilian Casualties Resulting from an Engagement on 12 July 2007 in the New Baghdad District of Baghdad, Iraq, at 4, If 9 (July 17, 2007).

92. Id., at 5 , 99

93. Arango \& Bumiller, supra note 89.

94. See discussion infra at $280-83$. 
A similar situation arose in connection with the Iraq war logs. In her chats with ex-hacker Adrian Lamo, ${ }^{96}$ Manning described how she had confronted her superior about American soldiers aiding the Iraqi government in arresting peaceful Iraqi dissidents. ${ }^{97}$ According to Manning, "[h]e didn't want to hear any of it. . . he told me to shut up and explain how we could assist the FPs [Iraqi Police Forces] in finding *MORE* detainees." 98

Internal whistleblowing in such a scenario would seem to be futile as superior officers appear to be complicit in international law-violating behaviour and it is impossible for the whistleblower to know how far and to whom this complicity extends. In such circumstances, would-be whistleblowers face a difficult decision, since pursuing an internal whistleblowing channel, which is unlikely to lead to results, may close off the possibility of subsequent external whistleblowing, either by directing suspicion onto the whistleblower or by enabling others to destroy evidence before it is possible to reveal the wrongdoing to external sources. This is particularly a risk when international law violations are systemic and therefore certainly, or very probably, involve those persons whom the whistleblower would normally be expected to confide in. Perhaps it was for this reason that neither Anat Kamm nor Katharine Gun pursued internal whistleblowing procedures. In Kamm's case, her military superiors and immediate boss, Yair Naveh, were all involved in formulating the concrete policy of targeted killing of Palestinian militants that Kamm perceived as contrary to international law. ${ }^{99}$ In Gun's case, the fact that she received the request to conduct surveillance on other UN Security Council members in casual e-mail form ${ }^{100}$ would seem to indicate that the proposed surveillance was a widely known practice within GCHQ; furthermore, she was officially working on behalf of a government very much in favour of the Second Iraq War-the very event which the surveillance was intended to facilitate - and willing to mete out savage treatment to persons impeding that goal. ${ }^{101}$ To expect that internal

95. The report instead put the onus on reporters to make themselves more visible to military personnel. See Memorandum for Commander, supra note 91.

96. After engaging in lengthy web chats with Manning, Lamo eventually reported her. Hansen, supra note 12.

97. Manning described their work, which he had arranged for an interpreter to read to him as "a scholarly critique." Id.

98. Id. The veracity of this incident was confirmed during Manning's trial. Transcript of Closing Argument at 135, United States v. Manning (2013), available at http://www.bradleymanning.org/wp-content/uploads/2013/06/072613amsession_F.pdf.

99. Uri Blau, IDF Ignoring High Court on West Bank Assassinations, HAARETZ, Nov. 26, 2008.

100. Burkeman \& Norton-Taylor, supra note 8.

101. See, e.g., the case of Dr. David Kelly who died in July 2003 after he shared information on Iraq's weapons capabilities that contradicted the government's official 
whistleblowing could adequately function in such an environment seems fanciful.

In short, when states are engaged in all but the most mild or isolated international law violations, internal whistleblowing mechanisms break down and whistleblowers turn to attempting to force state actors into compliance by exposing them to public pressure and condemnation through external whistleblowing. The European Court of Human Rights (ECtHR) has acknowledged in its jurisprudence the problem that system-wide internal failures could present for whistleblowers.

\section{Guja v. Moldova-Internal Whistleblowing "Clearly Impracticable"}

The case of Guja v. Moldova concerned a civil servant, Guja, who had released letters to the press that he believed showed high-ranking Moldovan officials intervening in criminal investigations. ${ }^{102}$ Dismissed from his post for revealing state secrets, ${ }^{103}$ Guja defended his actions on the grounds that the information he had disclosed was of major public interest and that he had been forced into public disclosure since Moldova lacked appropriate whistleblower legislation. ${ }^{104}$ Guja had felt unable to reveal the evidence to his superiors, since he had reasonable grounds to believe that they would simply destroy it. ${ }^{105} \mathrm{He}$ also claimed that he could not confide in Parliament as it was dominated by the Communist Party, in which the implicated officials were high-ranking members. ${ }^{106}$ The ECtHR decided in favour of Guja and found that:

the signalling by a civil servant or an employee in the public sector of illegal conduct or wrongdoing in the workplace should, in certain circumstances, enjoy protection. This may be called for where the employee or civil servant concerned is the only person, or part of a small category of persons, aware of

position. Andrew Gilligan, The Betrayal of Dr. David Kelly, 10 Years On, THE TELEGRAPH (July 21, 2013, 7:00 AM), http://www.telegraph.co.uk/news/politics/10192271/ The-betrayal-of-Dr-David-Kelly-10-years-on.html. Kelly was discovered as the source of the leak and bullied by government officials as a result of his disclosures. Id. It is possible that he took his own life as a consequence of this intimidation. Id. Although Kelly's death occurred several months after Gun leaked the NSA e-mail, it is indicative of the general atmosphere of hostility towards government employees speaking to the press on the issue of Iraq at the time.

102. Guja v. Moldova, 2008-II Eur. Ct. H.R., at 3-6, 9 ๆ 9-18 (2008).

103. Id. at $6,-21$.

104. Id. at 18 , $\uparrow$ - $61-62$.

105. Id. at $18, \uparrow 62$.

106. Id. 
what is happening at work and is thus best placed to act in the public interest by alerting the employer or the public at large.... In the light of the duty of discretion referred to above, disclosure should be made in the first place to the person's superior or other competent authority or body. It is only where this is clearly impracticable that the information could, as a last resort, be disclosed to the public. 107

The ECtHR decided that Guja was acting under this last resort scenario ${ }^{108}$ and "reiterates in this context that open discussion of topics of public concern is essential to democracy, and regard must be had to the great importance of not discouraging members of the public from voicing their opinions on such matters."109 Thus, the ECtHR decided that Guja's freedom of expression, as protected under Article 10 of the European Convention on Human Rights, had been violated when he was punished by dismissal for his disclosures. ${ }^{110}$

Of course, Guja's case was a civilian one and did not concern sensitive military information. Nonetheless, the "clearly impracticable" criterion could, at least in theory, be analogously applied in non-civilian situations, especially when grave breaches of international law are at stake. Even if legal protection is not extended to such whistleblowers, it should still be acknowledged that internal whistleblowing is at times impractical, and that simply not whistleblowing in such cases is a deeply unsatisfactory outcome for international law, given the critical role that external whistleblowing has filled in addressing serious and systematic violations. As the defence in Private Manning's trial stated, in situations where internal whistleblowing proves to be impractical, "giving something to a legitimate news organization is, unfortunately or fortunately, depending on what side of the fence you are on, the way we hold our Government accountable."111

\section{EXTERNAL WHISTLEBLOWING WITHIN THE FRAMEWORK OF INTERNATIONAL LAW}

Quite apart from the effectiveness of whistleblowing as an international law enforcement mechanism, however, is the question of how it fits, or could fit, into the broader framework of national and international law. This is, of course, no simple task. International law is a complex discipline fraught with contested versions of that law's substance, and military whistleblowers are prosecuted under domestic, not international

107. Id. at $21,9972-73$.

108. Id. at $23, \boldsymbol{\Phi} \mathbb{\top} 81-84$.

109. Id. at $25, \uparrow 91$.

110. Id. at $26,997$.

111. Transcript of Closing Argument, supra note 98, at 135. 
law, usually by the very government whose actions they have revealed. Any treatment of this issue must take all of these considerations into account. The remainder of this paper is devoted to a brief exploration of how whistleblowing could be embedded as an enforcement mechanism in the context of international law.

\section{A. The Tricky World of International Law}

An obvious objection to any integration of a role for whistleblowers in the international framework is the complexity of the subject matter at hand. Whistleblowers expose wrongdoing, ${ }^{12}$ but how, in the context of international law, does the whistleblower know when wrong has been done? There are many practices that are commonplace in international law; for example, vote-buying at international institutions, ${ }^{113}$ the domestic equivalents of which would be punishable under most national legal systems, but which do not breach any international law norms. Even in cases where a fairly clear and well-established international law norm is concerned, it can be difficult for a whistleblower to know whether or not the behavior in question has violated that norm. The fear is thus that any protection of such whistleblowers would open the floodgates to spurious, or well-meaning but erroneous, claims of international law violations, all of them potentially detrimental to the state's well-being. It is thus necessary to ask, in the interests of contemplating any future protective regime, what demands should be placed on the international law capabilities of the whistleblower to allow for exposure of international law violations, especially systemic violations, without unduly compromising state security. This is a difficult question and the following examples shed some light on this very problem.

\section{Anat Kamm-Targeted Killings}

While completing her compulsory military service in the Israel Defense Forces (IDF), Anat Kamm discovered documents which she believed revealed that the IDF had been conducting targeted killings of Palestinian

112. See Martin, supra note 2, at 122; Latimer \& Brown, supra note 3, at 768.

113. Ofer Eldar, Vote-Trading in International Institutions, 19 Eur. J. INT'L L. 3 (2008); Roslyn Fuller, Democracy and International Law: An Analysis of the Origins of Democracy, its Relationship with International Law and its Applicability to Modern Institutions 275-82 (2010) (unpublished thesis, Trinity College, Dublin, on file with the author). 
militants ${ }^{114}$ in a manner that not only contravened a 2006 Israeli High Court ruling, ${ }^{115}$ but which, in her view, constituted war crimes. ${ }^{116}$ On the basis of this conviction, Kamm copied, and requested fellow soldiers to copy for her, approximately 2,085 documents, including over 700 highly classified documents, onto $\mathrm{CD}$. Upon the conclusion of her military service, she provided 1,500 of those documents, including 150 highly classified and 330 classified documents, to journalist Uri Blau, ${ }^{117}$ who published a newspaper article based on the information. ${ }^{118}$

Some of the documents Kamm provided to Blau, and which he referenced in his publications, focused on the case of Ziad Malaisha. Malaisha was a leading figure in the Palestinian militant organization Islamic Jihad who had been killed by Israeli forces approximately six months after the Israeli High Court had delivered its interpretation of international humanitarian law norms vis-à-vis targeted killings. ${ }^{119}$ In its judgment, the Court, drawing on a wide background of scholarly opinion, essentially approved the policy of targeted killing, ${ }^{120}$ but subjected it to certain limitations, including that only those civilians directly taking part in hostilities could become the object of a targeted killing. ${ }^{121}$ Somewhat

114. Targeted killing is a pre-emptive military strategy employed by the IDF which entails killing known militants in surgical strikes in order to prevent them from participating in further attacks against Israel. See HCJ 769/02 Pub. Comm. Against Torture in Isr. v. Gov't of Isr. 2006(2) PD 459, 464, ๆ 2 [2006] (Isr.).

115. Id. at 465 .

116. Luvitch, supra note 10.

117. Abe Selig, Indictment Says Kamm Sought to Harm State Security, JerUSALEM Post (Aug. 4, 2010, 10:35 PM), www.jpost.com/Israel/Article.aspx?id=172699; Peled, supra note 9; Joanna Paraszczuk, Court Rules: Anat Kamm to Begin Prison Term, JERUSALEM POST, Nov. 18, 2011, at 6.

118. See Blau, supra note 99.

119. HCJ 769/02 Pub. Comm. Against Torture in Isr. v. Gov't of Isr. 2006(2) PD 459 [2006] (Isr.). Malaisha died in 2007. See Elad Benari, Who was Ziad Malaisha of the Anat Kam Affair?, SHALOM LIFE (Apr. 8, 2010), http://www.shalomlife.com/news/10205/ who-was-ziad-malaisha-of-the-anat-kam-affair/; Scandal over Israeli Army's Illegal Operations, RUSSIA TODAY (Apr. 14, 2010, 7:25 AM), http://rt.com/news/palestine-israel-army-killings/.

120. A position that enjoys widespread support in scholarly literature on the topic. See, e.g., J. Nicholas Kendall, Israeli Counter-Terrorism: Targeted Killings under International Law, 80 N.C. L. REV. 1069 (Mar. 2002) (arguing for the legality of targeted killings in Palestine); Howard A. Wachtel, Targeting Osama Bin Laden: Examining the Legality of Assassination as a Tool of U.S. Foreign Policy, 55 DuKE L.J. 677 (Dec. 2005) (differentiating between assassination and targeted killing in regards to Osama bin Laden); Jonathan Ulrich, The Gloves Were Never On: Defining the President's Authority to Order Targeted Killing in the War against Terrorism,45 VA. J. INT'L L. 1029 (Summer 2005); Philip Alston, The Challenges of Responding to Extrajudicial Executions: Interview with Philip Alston, 2 J. HuM. RTS. PRAC. 355 (Nov. 2010) (elaborating on the criteria to be used for determining the legality of a targeted killing).

121. HCJ 769/02 Pub. Comm. Against Torture in Isr. v. Gov't of Isr. 2006(2) PD 459, ๆ 60 [2006] (Isr.). 
controversially, however, the Court held that anyone who joins a "terrorist organization" which becomes his "home", and in the framework of his role in that organization commits a chain of hostilities with short periods of rest between them loses his immunity from attack "for such time" as he is committing the chain of acts; "[i]ndeed, regarding such a civilian, the rest between hostilities is nothing other than preparation for the next hostility." "22

Nevertheless, the Court stressed that even in such cases, the armed forces have a duty to observe the principle of proportionality in conducting missions and thus to do "everything possible to minimize collateral damage to the civilian population." 123 The Court specifically stated that this duty entails using less harmful means than targeted killing wherever possible. Therefore, "if a terrorist taking a direct part in hostilities can be arrested, interrogated, and tried, those are the means which should be employed," 124 and, though not always possible, arrest must "always be considered." 125 Ultimately, however, the Court accorded military forces wide discretion to determine when a strike should be deemed proportionate. ${ }^{126}$

Kamm's documents threw some light on precisely how the Court's decision was being implemented in practice within the IDF. These documents revealed that in a meeting on March 28, 2007, IDF Major General Yair Naveh had stated that in the course of a planned mission against Palestinian militants arrest was the preferred option, but if one of Islamic Jihad's leaders was identified, at which point he specifically named three men, including Malaisha, "the force has permission to kill them, according to the situation assessment while carrying out the mission." 127 In several follow-up meetings, senior officers ironed out the details of what they considered to be proportionate collateral damage to the assassination of Malaisha, prospectively in a travelling vehicle, including such suggestions as "another two people," not "more than five people,"

122. Id. at $9926,39$.

123. Id. at 26.

124. Id. at 40 (referencing McCann v. United Kingdom, 21 Eur. Ct. H.R. 97 (1995), in which three IRA members were shot dead by British agents in the streets of Gibraltar. In that case, the ECtHR had ruled that Britain's actions had contravened the European Convention on Human Rights).

125. HCJ 769/02 Pub. Comm. Against Torture in Isr. v. Gov't of Isr. 2006(2) PD 459, ๆ 40 [2006] (Isr.).

126. Id. at 59.

127. Blau, supra note 99. 
and not more than one unidentified person. ${ }^{128}$ The military also classified Malaisha's arrest as "impractical" and according to the documents obtained had listed arrest only as an "alternative action," 129 an assessment which could be questioned in light of the fact that Malaisha had previously been arrested and had spent over three years in jail. ${ }^{130}$ Despite these preparations, the mission was never realized and Malaisha was killed in a gun battle that erupted during an Israeli raid into the West Bank. ${ }^{131}$ Notwithstanding the ultimate outcome of the particular case of Malaisha, Kamm felt that the IDF's approach to targeted killing, revealed in the documents she released, violated international law. ${ }^{132}$

Whether the IDF's actions were compliant with international law thus depends on two factors: first, was the High Court's interpretation of the international laws of warfare correct, and second, was it faithfully implemented by the IDF?

While Malaisha had undoubtedly made a "terrorist organization" his "home" and was thus according to the Israeli Court's definition, theoretically a legitimate mark for targeted killing, the Court's decision itself is but one interpretation of international law and has been criticized for, among other things, allegedly erroneously qualifying the conflict between Israel and Palestinian militias as international in nature. ${ }^{133}$

It is suggested here that in declaring all those who have joined a "terrorist organization" to be constantly taking part in hostilities, even when engaged in activities that are not at all related to the conflict, the Court may have interpreted Article 51(3) of the First Protocol to the Geneva Conventions ${ }^{134}$ too widely. This interpretation would appear to assess the time period under which a person can be qualified as "directly taking part in hostilities" in rather generous terms and thus allow militia leaders to be targeted while engaged in such mundane and non-threatening activities as buying

128. Id.

129. Uri Blau, IDF Rejects Claims it Killed Palestinians in Defiance of Court, HAARETZ, Nov. 27, 2008.

130. Tzvi Ben Gedalyahu, Haaretz's Alleged 'Reporter Spy' Studied under AntiZionists, ARUTZ SHEVA (Nov. 4, 2010, 12:28 PM), http://www.israelnationalnews.com/ News/News.aspx/136931; Benari, supra note 97.

131. Scandal over Israeli Army's Illegal Operations, supra note 119.

132. Specifically referring to them as "war crimes". Luvitch, supra note 10; Ofra Edelman, Anat Kam: I stole IDF Documents to expose West Bank War Crimes, HAARETZ (Apr. 12, 2010, 4:30 PM).

133. Orna Ben-Naftali \& Keren Michaeli, Legality of Preventive Targeted Killings - International Armed Conflict, 101 AM. J. INT'L L. 459 (2007).

134. Article 51(3) states that civilians directly participating in hostilities lose their protection from military attack. Protocol Additional to the Geneva Conventions of 12 August 1949, and Relating to the Protection of Victims of International Armed Conflicts (Protocol I) art. 51, ๆ 3, June 8, 1977, 1125 U.N.T.S. 3. 
groceries or watching television. ${ }^{135}$ While the Court self-corrected this seemingly wide interpretation of Article 51's wording by requiring observance of proportionality, ${ }^{136}$ the IDF may have overstepped the Court's boundaries in regards to proportionality in pre-determining Malaisha's arrest to be impractical. Thus, if a war crime did exist, it could only lie in the combination of the Court's relatively wide interpretation of Article 51(3) of the First Protocol and the IDF's plan to slightly overstep the boundaries set by the Court's guidelines on proportionality. With regards to international law, the entire situation could thus perhaps best be described not as a flagrant violation, but as "pushing the envelope." Moreover, as the proposed mission in regards to Malaisha was never realized, Kamm's disclosures did not so much reveal a specific war crime as raise questions about how other targeted killings may have been conducted. Thus, in a case where even the Israeli High Court had felt that the exact contours of legitimate targeted killing were difficult to assess, ${ }^{137} \mathrm{Kamm}$ took it upon herself to interpret where that precise boundary lay.

This is not to suggest that Kamm did not believe that war crimes were being perpetrated, nor does it diminish the importance of revealing information in an atmosphere where lives are at stake. It merely illustrates the difficulty posed by whistleblowing in international law of ascertaining what the law is in an area where hard contours are unclear even to practitioners. The Tel Aviv District Court took note of this point during its investigation: According to Justice Ze'ev Hammer, as expressed in

135. Or, for example, a lengthy return to one's residence to engage in mundane household chores, to care for one's relatives, or to participate in religious or social activities, such as a marriage in the family. Alternatively, one could imagine a falling-out with other members of the organization leading to a lengthy cessation of activity.

136. Presumably it would be less problematic to effect an arrest in situations where the militant is not presently directly engaged in armed activity.

137. The Court, in fact, noted that it was beyond its abilities to exhaustively describe when a civilian could be considered to be taking a direct part in hostilities. HCJ 769/02 Pub. Comm. Against Torture in Isr. v. Gov’t of Isr. 2006(2) PD 459, ๆף 33-37 [2006] (Isr.). Nevertheless, it circumscribed a fairly wide array of activities, which in its view could certainly be subsumed as "direct participation in hostilities", including: preparing oneself for hostilities; collecting intelligence on the army; transporting unlawful combatants to or from a place where hostilities are taking place; operating weapons or supervising their operation; or driving a truck of ammunition to a place where it will be used for the purposes of hostilities. Id. The Court also decided that anyone acting as a human shield out of "their own free will" was taking a direct part in hostilities, as were participants up the entire chain of command, including those who send a militant on his mission, those who plan the attack, and those who decide that the attack should be carried out. Id. 
his summation, Kamm had "failed to explain her sudden expertise in international law and the highly complex definition it gives for war crimes."138 The Supreme Court in its decision on Kamm's sentencing appeal also weighed in on this theme, accusing Kamm of taking the law into her own hands ${ }^{139}$ and of usurping the position of a lawyer. ${ }^{140}$

This focus on the whistleblower's level of expertise is worth considering; after all, how can a whistleblower claim to be acting in the interests of international law enforcement when they do not possess clear information regarding the content of international law? Equally, how could a whistleblower form the reasoned conviction that an international law violation has occurred in what many experts would consider to be, at most, a borderline case? Conversely, if a whistleblower is in a position to know that a war crime has been committed, would disclosing that information, potentially even to the public, as Kamm did, be more easily justified?

Focusing on the whistleblower's knowledge raises some important points for consideration: what of the case where the whistleblower was not in a position to accurately assess whether an international law violation had been committed, but nevertheless revealed what any expert would acknowledge to be a serious, if subtle, violation, such as a breach of territorial sovereignty, the laws of the sea, or the Vienna Convention on Diplomatic Relations? Alternatively, had Kamm exposed a sufficiently flagrant violation of international law, such as a planned genocide or aggressive war, would the court have considered that she was in a position to know that this represented a violation of international law even without "expertise" or formal training? ${ }^{141}$ In other words, would the court accept that the non-specialist, while possibly unaware of the intricacies involved, possesses some rudimentary knowledge of the most fundamental points of international law? After all, not all violations of international law are subject to "highly complex" definitions: genocide and aggressive warfare, in particular, can be committed in quite straightforward, obvious fashion.

Despite these questions, which must at this point remain open, the Israeli courts' interest, fleeting as it was, in a differentiated level of knowledge in relation to a whistleblower's right to make disclosures in the pursuit of enforcing international law norms remains a useful approach to a difficult situation, one that finds parallels in domestic law. ${ }^{142}$

138. Luvitch, supra note 10. \ 6.

139. CrimA, 8445/11 Anat Kamm v. State of Israel PM 17959(01) 10, [2011] (Isr.),

140. Id. 919.

141. Luvitch, supra note 10.

142. See discussion infra at 287. 


\section{Katharine Gun-The Second Iraq War}

Kamm's case is far from the only example of the difficulties posed in ascertaining the existence of an international law violation. The case of Katharine Gun presents perhaps the most significant conundrum vis-àvis the particular vicissitudes of international law. Gun was employed as a translator for Government Communication Headquarters (GCHQ), a British intelligence agency. On January 31, 2003, she received an e-mail from the USA's National Security Agency (NSA) requesting help in tapping the phones of six UN Security Council members, an action likely contemplated in the service of giving the USA and UK an edge in the negotiations on Security Council authorization for military action against Iraq. ${ }^{143}$ Gun leaked the e-mail to a friend whom she knew to have contacts with journalists and the story was eventually published. ${ }^{144}$ She later reported herself as the source of the story. ${ }^{145}$

While bugging the UN missions of other states, and in particular tapping the phones of these nations' UN representatives, ${ }^{146}$ would have contravened the Vienna Convention on Diplomatic Relations, ${ }^{147}$ it does not appear that this was the international law violation that motivated Gun to leak the e-mail to the press. Instead, Gun described her motivation as an attempt to prevent the Second Iraq War and thereby save lives, specifically stating, after being charged under Section 1 of the UK's Official Secrets Act of 1989, "I will defend the charge against me on the basis that my actions were necessary to prevent an illegal war in which thousands of Iraqi civilians and British soldiers would be killed or maimed."148

Ironically, however, the Second Iraq War remains illegal only because the US and UK failed to procure the desired Security Council resolution, an outcome to which Gun's actions arguably contributed. Had a Security Council resolution clearly authorizing force been obtained, the war would have been legal under international law, and it is uncertain, at best, that this legality would be reversed by any subsequent revelation that the US and UK had used intelligence obtained via violations of the Vienna

143. Burkeman \& Norton-Taylor, supra note 8.

144. Id.

145. Id.

146. Ex-GCHQ Officer 'Preventing War', supra note 11.

147. See Vienna Convention on Diplomatic Relations arts. 22, 27 I 2, Apr. 18, 1961, 500 U.N.T.S. 95.

148. Ex-GCHQ Officer 'Preventing War', supra note 11. 
Convention on Diplomatic Relations to manipulate other Security Council members into voting in line with their wishes. ${ }^{149}$ Thus, if Gun had refrained from making her disclosure, and surveillance of the Security Council swing states had given the US and UK an advantage sufficient to have the resolution authorizing force passed, the crime of aggression would, for all intents and purposes, not have been committed. Thus, as strange as it might sound to the non-international law practitioner, Gun's actions may have, from a conditio sine qua non perspective, led to more serious international law violations than would otherwise have been the case.

Although the case against Gun eventually collapsed when the prosecution chose not to offer evidence, it does raise some questions as to the extent of knowledge a whistleblower should have in relation to the international law violations they intend to disclose. Gun had a general idea that international law was being violated, but did not appear to have been fully aware of the precise nature of that violation, given that her intentions on this point seem to have been more attached to the possibility of a war than to the surveillance of other nations (although she recognized that the surveillance was incorrect, she does not appear to have recognized its full legal significance). Considering the intricacies of international law, which so often differ from accepted domestic legal norms, this is a point worth considering. Is it acceptable for whistleblowers to view themselves as instruments for enforcing international law in cases where they technically contribute to enforcing a somewhat different, but related, international law norm than they intended to? Or should only those whistleblowers whose intentions and knowledge attach to the correct international law norm be viewed as credible instruments of international law enforcement? These are not necessarily insurmountable difficulties, but they do reveal some of the issues raised when we attempt to fit whistleblowers into the general scheme of international law.

149. There is no acknowledged method of reviewing Security Council resolutions for their legality-indeed, the ICJ has declined to do so in the past. See, e.g., Legal Consequences for States of Continued Presence of South Africa in Namibia (South West Africa) Notwithstanding Security Council Resolution 276 (1970), Advisory Opinion, 1971 I.C.J. 16, at 23 (June 21). Even if the ICJ were to take the unprecedented step of reviewing a Security Council resolution, the chain of causality in such a situation would be difficult to prove, especially against the backdrop of the Security Council's decisionmaking process in which intense pressure is routinely employed to garner the required number of votes in favour of resolutions. See Eldar, supra note 113, at 3-41; Fuller, supra note 113 . 


\section{Chelsea Manning-Cablegate, War Logs and "Collateral Murder"}

Despite being the source of possibly the biggest leak in history, Private Manning did not make a conclusive judgement on the legality or illegality of the actions she exposed. Although Manning had not read all of the diplomatic cables she leaked and much of the information contained there in is frivolous, ${ }^{150}$ in her chat logs with Adrian Lamo, Manning characterized some of the activities recorded in the cables as "crazy, almost criminal political backdealings" and expressed the hope that her actions "might actually change something." 151 She later reiterated this sentiment in her formal statement to court: "The more I read, the more I was fascinated by the way we dealt with other nations and organizations. I soon began to think the documented backdoor deals and seemingly criminal activity didn't seem characteristic of the de facto leader of the free world." 152

Unlike Kamm, and to some degree Gun, Manning thus refrained from making a clear judgment on the legality of the actions she exposed, and seems to have restricted herself to the position that it was plausible for her to justifiably suspect that they might be illegal. In this she was at least partially correct: some of the cables released to Wikileaks have shed light on international law violations, for example wilful deficiencies in combatting drug trafficking ${ }^{153}$ and illegal logging. ${ }^{154}$ Government complicity in more serious international law violations is also recorded in certain cables pertaining to Sri Lanka. In one cable, U.S. embassy officials state that "responsibility for many of the alleged crimes [in relation to an

150. It should be noted, however, that much of this frivolous information was only released to the public following a breach of Wikileaks data security. See James Ball, Unredacted US Embassy Cables Available Online After Wikileaks Breach, THE GUARDIAN, Aug. 31, 2011, at 11.

151. Hansen, supra note 12.

152. Bradley Manning's Personal Statement to Court Martial: Full Text, THE GUARDIAN (Mar. 1, 2013, 5:58 PM), http://www.theguardian.com/world/2013/mar/01/bradleymanning-wikileaks-statement-full-text.

153. E.g., Aircraft Down in Honduras and the Seizure of 3.3 Kilos of Cocaine, WIKILEAKS (Oct. 28, 2002, 3:26 PM), http://wikileaks.org/cable/2002/10/02TEGUCIGAL PA2966.html; Serbia: Fingerpointing Continues in Major Organized Crime Case, WiKILEAKS (Feb. 24, 2010, 5:37 PM), https://www.wikileaks.org/plusd/cables/10BEL GRADE35_a.html (indicating involvement between government and drug traffickers).

154. The Two Papuas: A Consul General's View, supra note 20 (recording allegations made by Papua New Guinea's Consul in Jayapura to the effect that the Indonesian Armed Forces are involved in illegal logging and drug smuggling in Papua New Guinea). 
extensive government offensive against armed rebel group the Tamil Tigers in 2009] rests with the country's senior civilian and military leadership, including President Rajapaksa and his brothers and opposition candidate General Fonseka." 155 Another cable alleges that the Sri Lankan government was colluding with paramilitary groups in criminal activities including "extrajudicial killings, abductions, [and] child trafficking." are serious violations of international human rights and humanitarian law.

Similarly, the Iraq and Afghan war logs and related cables reveal evidence of further human rights violations and complicity in human rights violations. Examples of these violations include, turning over Iraqis to Iraqi police in cases where torture was suspected; failing to exercise proportionality in actions against insurgents or suspected insurgents, resulting in thousands of civilian deaths; and failing to prevent defence contractors from engaging in the use of so-called "bacha bazi" (dancing boys, often also used as child prostitutes) in Afghanistan. ${ }^{157}$

The most visually arresting evidence of the international law violations revealed by Manning are those depicted in the video footage now known as 'the Collateral Murder video'. This recording originates from the camera of an Apache helicopter gunship deployed over Baghdad during a military operation. ${ }^{158}$ It appears that, while observing a group of armed men walking through the city, the crew's suspicions were raised when one of the cameramen furtively peered around a street corner at a US military vehicle parked one hundred meters away and then raised his camera to his face to make a recording. ${ }^{159}$ The gunship's crew apparently mistakenly

155. Sri Lanka War Crimes Accountability: The Tamil Perspective, supra note 20

156. Sri Lanka: GSL Complicit in Paramilitary Factions Human Rights Abuses, supra note 20.

157. Batty \& Doward, supra note 19; David Leigh, Afghanistan War Logs: Secret CIA Paramilitaries' Role in Civilian Deaths, THE GuARDIAN (July 25, 2010, 5:33 PM), http:// www.theguardian.com/world/2010/jul/25/afghanistan-civilian-deaths-rules-engagement; John Nova Lomax, Wikileaks: Texas Company Helped Pimp Little Boys to Stoned Afghan Cops, Houston PRESS (Dec. 7, 2010, 7:01 AM), http://blogs.houstonpress.com/hairballs/ 2010/12/wikileaks_texas_company_helped.php; Jon Boone, Foreign Contractors Hired Afghan 'Dancing Boys', Wikileaks Cable Reveals, GuARDIAN (Dec. 2, 2010, 4:30 PM), http://www.theguardian.com/world/2010/dec/02/foreign-contractors-hired-dancing-boys. Regarding the bacha bazi, there is no direct evidence that the boys were abused on this particular occasion. See Rachel Slajda, State Dept.: No One Touched 'Dancing Boy' at DynCorp Party, TPM (Dec. 9, 2010, 7:48 PM), http://talkingpointsmemo.com/muck raker/state-dept-no-one-touched-dancing-boy-at-dyncorp-party. Nonetheless, Afghan authorities were prompted to make numerous arrests relating to the incident. Meeting, Assistant AMB Mussomeli and MOI Minister Atmar: Kunduz Dyncorp Problem, Transport for Presidential Candidates and Other Topics, WIKILEAKS (June 24, 2009, 11:37 AM), https://www. wikileaks.org/plusd/cables/09KABUL1651 a.html.

158. Elisabeth Bumiller, Video Shows 2007 Air Attack in Baghdad That Killed Photographer, N.Y. TIMES, Apr. 6, 2010, at A13.

159. Memorandum for Commander, supra note 91, at 1-2. 
believed that he was raising a rocket-propelled grenade launcher to shoot at the vehicle. ${ }^{160}$ As a result, the pilots opened fire on the group of men, killing several of them and seriously wounding one of the cameramen, later identified as Saeed Chmagh, an employee of Reuters news agency. ${ }^{161}$ The gunship crew noted that Chmagh was wounded and observed his attempts to crawl away from the scene of the incident. ${ }^{162}$ Shortly thereafter, a van arrived at the scene. The driver of this vehicle and two other men attempted to load Chmagh into the van. ${ }^{163}$ The helicopter crew falsely reported this to ground control as persons picking up bodies and weapons in an effort to prevent American forces from later examining them. ${ }^{164}$ The gunship crew thereby gained permission to fire and did so, killing Chmagh and the driver of the vehicle (later identified as Saleh Mutashar), ${ }^{165}$ and seriously wounding the driver's two children who had been in the van. ${ }^{166}$ This second incident is particularly problematic from an international law perspective.

Even without classifying the precise nature of the conflict, ${ }^{167}$ a number of violations of customary international humanitarian law are apparent from the video footage: the duty to distinguish between civilians and combatants, the duty to act with proportionality (even if Mutashar had been removing evidence from the battlefield, the gunship crew could have first attempted to dissuade him by using non-targeted force or simply tracked the van from their vantage point), and the duty to exercise care

160. Id

161. Arango \& Bumiller, supra note 89.

162. See minute 6:15-9:01 in the unedited footage from the gunship's camera. See wordswithmeaning, supra note 14, also Arango \& Bumiller, supra note 89.

163. See minute 6:15-9:01 in the unedited footage from the gunship's camera. See wordswithmeaning, supra note 14 .

164. The crew makes this claim repeatedly between minute $7: 32$ and $8: 28$ in the unedited footage. See wordswithmeaning, supra note 14.

165. The other two "good Samaritans" may also have perished in the incident.

166. US soldier on Aftermath of Wikileaks Apache Attack, BBC News (Oct. 28 2010, 7:10 PM), http://www.webcitation.org/5yGAVeN6S; Families of Victims of 2007 US Helicopter Killing React to Leaked Video, DEMOCRACY Now (Apr. 12, 2010), http://www.democracynow.org/2010/4/12/families_of_victims_of_2007_us.

167. The incident took place on July $12,20 \overline{0}$, at which point Iraq was no longer officially occupied and the foreign troops on its territory were present on the basis of Security Council Resolution 1546 (S.C. Res. 1546, U.N. Doc. S/RES/1546 (June 8, 2004)). See David Turns, The International Humanitarian Law Classification of Armed Conflicts in Iraq Since 2003, in 86 The WaR IN IRAQ: A Legal ANALYSis 97, 98, 111 (Raul A. Pedrozo ed., 2010). 
in not targeting journalists. ${ }^{168}$ Customary international humanitarian law also prohibits attacking persons who are hors de combat ${ }^{169}$ unless they are attempting to escape. This is precisely how the military investigator chose to construe Mutashar's efforts to load Chmagh into his van-as an attempt at escape. ${ }^{170}$ However, the wounded must also receive medical care without delay, ${ }^{171}$ and Chmagh was obviously seriously wounded at the time that Mutashar arrived. It is, we now know, extremely improbable that Mutashar was helping Chmagh flee the scene of hostilities, given he was not an insurgent, but a journalist, and therefore devoid of a reason to flee. Rather, it seems overwhelmingly probable that Mutashar's intention was to convey Chmagh to a location where he could receive medical attention. Moreover, the gunship crew appeared to know that permission to fire would not be granted if they communicated a true version of events to ground control. Thus, they lied in saying that Mutashar was picking up bodies and weapons; they knew this to be untrue for the very good reason that at that point Chmagh was not a dead body, but in fact very much alive. It is difficult, under even the most lenient interpretation of events, to understand how the gunship's crew could have reasonably interpreted Mutashar's actions as helping "insurgents" to escape in a manner that required the immediate use of lethal force, which endangered not only Mutashar and Chmagh, but also the two unnamed "good Samaritans" and Mutashar's children.

This viewpoint was shared by many others in the immediate aftermath of the video's release, including Clive Stafford-Smith, a U.S.-British human rights lawyer who stated, "I don't think there's any question that this is a violation of the Geneva Conventions," as well as Chris Cobb-Smith, a former British army officer, who stated "[e]ngaging the people picking up the wounded is outrageous.... That is against all humanitarian law and the rules of conflict-most definitely and without a doubt." ${ }^{, 172}$ Others, such as Bibi van Ginkel, a senior fellow at the Clingendael Netherlands Institute of International Relations, were more cautious, stating, "[m]y first guess would be that a war crime was committed. Very simply speaking,

168. Jean-Marie Henckaerts, Study on Customary International Humanitarian Law: A Contribution to the Understanding and Respect for the Rule of Law in Armed Conflict, 87 InT'L ReV. Red Cross, no. 857, March 2005, at 175, 198, rule 1, 199, rule 14,201 , rule 34 .

169. Id. at 203 , rule 47

170. Memorandum for Commander, supra note 91 , at 4

171. Henckaerts, supra note 168 , at 207 , rule 110.

172. John Cooke, Exclusive: Reuters Chief Spikes Story on Killing of his Own Staffers in Baghdad, GAWKER.COM (Apr. 8, 2010, 1:09 PM), http://gawker.com/5512623/ exclusive-reuters-chief-spikes-story-on-killing-of-his-own-staffers-in-baghdad (noting that the original story was filed by Luke Baker on April 7, 2010). 
if people are helping the wounded, they are non-combatants. If force is used against them, then that is a war crime."173

The balance of opinion would appear to be that, by releasing the Collateral Murder video, Manning conveyed evidence of serious international law violations.

However, despite the wealth of probable crimes that Manning revealed, she seems to have stopped short of actually holding a concrete belief that international law violations had been committed. Instead, she chose to reserve judgement on this point.

Thus, in only these three cases, occurring within the space of just seven years, we have one whistleblower (Kamm) who held the certain belief that an international crime was committed, but in reality had merely disclosed the possibility that a violation may have been contemplated; another (Gun) who revealed a violation of international law, although not the precise violation that she thought she was revealing; and a third (Manning) who revealed dozens of near-certain grievous violations of international law, but who formed no solid opinion on the legality or illegality of the actions revealed. Jurisprudence on this particular point is even more scarce since Gun's trial collapsed when the prosecution chose not to offer evidence, and points of international law played no appreciable role in Manning's trial. Only in Kamm's case did the courts briefly address the issue of the whistleblower's mental assessment of the legality or illegality of the facts disclosed.

These cases highlight the fact that we are faced with a situation today in which many people have an inkling of international law, but few clear ideas regarding its precise substance. Nonetheless, they may feel beholden to enforce these vaguely perceived norms, especially in instances where the lives of others are threatened. Any decision on whether to grant external military whistleblowers the status of potential international law enforcers or to offer them protection must therefore balance two different goods: on the one hand, as in all legal systems, violations cannot be effectively prevented or punished when those capable of suppressing the violation have no knowledge of it; ${ }^{174}$ on the other hand, letting military

173. Id.

174. For this very reason, a wide range of tools are available on the national level to encourage a free flow of information; for example, laws which obligate all persons within a state's jurisdiction to inform the authorities of certain forms of impending criminal activity. See, e.g., Sec. 138 German Criminal Code, Sec. 9(1) of the Irish Offences against the State Act (a provision which is used between 60 and 120 times a year. See Oireachtas 
whistleblowers release their information publicly when they do not know or even have concretely formed ideas on whether or not the behaviour concerned violates international law is a risky prospect, especially when such information is militarily sensitive. Nonetheless, due to the serious nature of international law violations, many of which cause irreparable damages to the victims, and also the inefficacy of internal whistleblowing mechanisms in combatting the most widespread and systematic instances of international law-violating behaviour, it is submitted here that states should consider introducing legislation which protects external whistleblowing in certain cases where international law has been breached, and that international organizations should consider introducing multilateral instruments which could be helpful in this regard. After all, states have committed to observing the international law norms in question in all of the above cases; it is contradictory to punish, and punish harshly, those who help in attaining that compliance.

However, as the above cases demonstrate, any efforts in this direction will need to contemplate the level of certainty which an external whistleblower should possess concerning the existence of international law violations in those cases where sensitive information is disclosed. National laws may offer some guidance in this regard; national civilian whistleblower protection laws generally do not require that whistleblowers act with certainty in regards to the violations they report, but merely that they act "on the basis of reasonable belief," even in some instances permitting external disclosure on this basis. ${ }^{175}$ Such a standardimplemented on a state by state basis - need not be uniform, but could demand 'reasonable belief' (as in national whistleblower laws), 'belief

Library \& Research Service, supra note 1, p. 7); see also Secs. 38b and 39 UK's Prevention of Terrorism Act of 2000 (which was the principal offence in 22 cases between 2001 and 2009. Oireachtas Library \& Research Service, supra note 1, p. 8); Additionally, there are protection programmes which facilitate witnesses to give testimony by mitigating the danger of reprisals. For example, the Witness Security Program in the USA, established on the basis of Title V of the Organized Crime Control Act 1970, or the Canadian Federal Witness Protection Program, established by the Witness Protection Program Act 1996.

175. For example, Canada Public Servants Disclosure Protection Act, Section 12 states, "[a] public servant may disclose to his or her supervisor . . . any information that the public servant believes could show that a wrongdoing has been committed or is about to be committed, or that could show that the public servant has been asked to commit a wrongdoing." Canada Public Servants Disclosure Protection Act, S.c. 2005, c.46, § 12 (Can.). The US Whistleblower Protection Act of 1989 protects the whistleblower who "reasonably believes" that their disclosure reveals a violation of the law or gross mismanagement. Whistleblower Protection Act, 5 U.S.C. § 2302(b)(8) (1989). Section $43 \mathrm{~B}$ of the UK Public Interest Disclosure Act covers disclosures made under the "reasonable belief" that they "tend to show" certain listed situations, such as a criminal offence (Sec. 43B(1)(a)) or a miscarriage of justice (Sec. 43B(1)(c)). Public Interest Disclosure Act, 1998, c.23, § 43B (U.K.). 
grounded on factual evidence,' or 'near certainty.' Conversely, protection could be predicated on the whistleblower releasing their information in a manner which does not inflict any proven harm on the state concerned. Setting a knowledge bar, especially when exercised in conjunction with the 'last resort' requirement as developed by the ECtHR in Guja, and improved training in the field of international law for all military personnel, would help to dissuade spurious or well-meaning, but erroneous, cases of external whistleblowing while establishing a safety valve to facilitate disclosures of the worst international law violations in a manner that does not demand unreasonable sacrifices on the part of the whistleblower.

\section{B. The Difficulty of Justification in a Dualist System}

As the foregoing considerations indicate, the key difficulty in protecting those whistleblowers who publicly reveal international law violations stems from the tension inherent to dualist systems, namely that, in revealing international law violations, whistleblowers often break domestic laws and are subject to strict penalties. ${ }^{176}$ On the surface, these cases seem clear-cut: the whistleblower has made a disclosure which is specifically excluded from the protection of domestic laws ${ }^{177}$ and has thereby made

176. Manning was originally charged with numerous infringements of the US's Uniform Code of Military Justice (UCMJ). Some of these charges were incidental to her final purpose, such as transferring classified data onto her personal computer (UCMJ Art. 92), while others were more serious, such as communicating national defence information to an unauthorized source (charged under UCMJ Art. 134), and "aiding the enemy" (UCMJ Art. 104). These were later supplemented by charges brought under the Espionage Act of 1917. See Uniform Code of Military Justice arts. 92, 134, 104, 10 U.S.C. $\S \S 892,934,904$ (1956); Charlie Savage, Manning is Acquitted of Aiding the Enemy, N.Y. TIMES, July 31, 2013, at A1; Wikileaks Source Manning Convicted on Most Charges, BBC News (July 30, 2013, 6:01 PM), http://www.bbc.co.uk/news/world-uscanada-23506213.

Anat Kamm was initially charged with espionage and deliberately intending to harm state security, an offence which carries a maximum punishment of life imprisonment. This charge was dropped in exchange for her admitting to charges of possessing and passing on classified material, which carries a maximum sentence of 15 years imprisonment. Paraszczuk, supra note 119; Ofra Edelman, Closed-Door Trial Gets Underway for ExSoldier Accused of Passing Classified Documents to Haaretz Reporter, HAARETZ, May, 24, 2010. Katharine Gun was charged with disclosing damaging security information under Section 1 of the UK's Official Secrets Act of 1989. Ben Davies, Interview: Whistleblower Katharine Gun, BBC NEws (Sept. 15, 2004, 4:02 PM), http://news.bbc.co. uk/2/hi/uk_news/politics/3659310.stm.

177. Gun's disclosure was not protected under the UK Public Interest Disclosure Act of 1998, article 1, section 43, because according to section 43B(3), a disclosure does 
themselves susceptible to punishment. Thus far, this article has contemplated legal alterations which may help to overcome the undesirable consequences of dualism in these cases. However, this may leave the case for increased whistleblower protection open to the criticism that such a regime, whether agreed upon multilaterally or subject to state-by-state regulation, is very much de lex ferenda and thus so farfetched as to be barely worthy of current contemplation - at best an academic construct which finds little application or traction in the real world. An investigation of national jurisprudence, however, indicates otherwise. National jurisprudence on this issue has been quite differentiated and few courts have unequivocally denied the possibility that external whistleblowing, even of classified or sensitive information, could be justified in certain circumstances.

In arguing for their own exoneration, military and intelligence whistleblowers have traditionally pursued a line of defence that revolves around two closely related concepts: higher necessity and a conflict of duties. In recent times this has taken on an added twist: the whistleblower points out that they were obliged to break domestic laws in order to reveal violations of international law. This strategy could either be based on a monist conception of the relationship between international and domestic law, or could reflect a belief that national laws designed to implement international laws and give effect to international obligations are not being observed. Courts have shown a variety of nuanced reactions to these defences, even to the point where some tentative jurisdictional trends may be observed.

\section{Higher Necessity—Mordechai Vanunu and Ryszard Kuklinski}

Neither Mordechai Vanunu nor Ryszard Kuklinski claimed to reveal violations of international law. However, as military and intelligence whistleblowers who chose to defend their actions, their cases represent precedent which is, in some respects, still relevant today. The case of Mordechai Vanunu holds to the classic perception of how military whistleblowers could be expected to be treated in cases where they clearly breach their duties of confidentiality, while Ryszard Kuklinski's case resulted in a very different outcome.

not qualify for protection if the person making the disclosure thereby commits an offence. Public Interest Disclosure Act, 1998, c.23, § 43B (U.K.); see also Davies, supra note 176. Similarly, Manning could not rely on the Military Whistleblower Protection Act of 1998, which allows for disclosure only to certain categories of people, such as members of Congress. 
In the early 1980s, Vanunu, an Israeli citizen, was employed as a nuclear technician at Israel's Negev Nuclear Research Center (also known as the "Dimona facility"), where he was bound by a confidentiality agreement. ${ }^{178}$ Sometime after commencing work at the Dimona facility, Vanunu realized that his workplace was manufacturing nuclear weapons on a large scale. ${ }^{179}$ Vanunu was angered to learn of this production, which was being carried out in secret without the knowledge or consent of most Israeli citizens. ${ }^{180}$ In early 1985 , he took nearly sixty photos which revealed the nuclear weapons production inside the Dimona facility before leaving Israel and eventually selling the photos to two British newspapers in $1986 .{ }^{181}$ Before the story was published, Israeli intelligence agents abducted Vanunu in Italy ${ }^{182}$ and returned him to Israel, where he was convicted by the Jerusalem District Court of treason and aggravated espionage under Section 113(b) of the Israeli Penal Code. ${ }^{183}$ When Vanunu appealed to the Supreme Court in 1990, the Court rejected his argument that he had been serving a higher goal (the democratic character of the state) which overrode his duty to maintain secrecy, endorsing the District Court's view that ideology could not be taken into consideration, as it could be made to justify any action. ${ }^{184}$ Vanunu ultimately spent eighteen years in prison, ${ }^{185}$ eleven of them in solitary confinement. ${ }^{186}$

Despite being argued on similar lines, the outcome could not have been more different in the contemporaneous case of Colonel Ryszard Kuklinski. Like Gun and Vanunu, Kuklinski desired to avert the consequences of armed conflict; in his case the outbreak of hostilities between the USA and USSR during the Cold War. A high-ranking strategy officer in the Polish army, Kuklinski had good reason to fear that should hostilities erupt between the Soviet Union and NATO States, Poland

178. Feldman, supra note 5, at 10

179. Based on the plant's production processes, Vanunu estimated output at 200 nuclear weapons. Id.

180. Feldman, supra note 5, at 10; Vanunu: Traitor or Prisoner of Conscience?, SYDNEY MORNING HERALD, Apr. 22, 2004.

181. Vanunu: Traitor or Prisoner of Conscience?, supra note 180.

182. Greg Myre, Israeli who Revealed Nuclear Secrets is Freed, N.Y. TIMES, Apr. 21, 2004.

183. Olenka Frenkiel, Israeli Nuclear 'Power' Exposed, BBC News (Mar. 16, 2003), http://news.bbc.co.uk/2/hi/programmes/correspondent/2841377.stm.

184. Feldman, supra note 5, at 13.

185. Vanunu: Traitor or Prisoner of Conscience?, supra note 180.

186. Michael Omer-Man, This Week in History: Vanunu Convicted for Treason, JERUSAlEM Post, Jan. 4, 2011. 
would be utterly destroyed in a short-range nuclear war. In an attempt to save his country from this fate, he contacted the U.S. Embassy in Bonn and leaked approximately 35,000 pages of classified Soviet military information to the CIA between 1972 and 1981. ${ }^{187}$ Kuklinski's purpose in leaking these documents was to convince the USA to alter its "World War III" strategy from that of short-range nuclear attack in the middle of Europe to a more tactical disruption of Soviet battle units in the USSR, thus shifting the battleground away from Polish territory. Following his escape to the USA in $1981,{ }^{188}$ Kuklinski's activity was discovered, and on May 23,1984 , he was sentenced to death in absentia by a unanimous decision of the Warsaw District Military Tribunal, which stated that he had caused immeasurable damage to the state security of the entire Eastern Bloc through the crimes of betrayal and desertion (under articles 122 and 303 of the Criminal Code of the People's Republic of Poland). ${ }^{189}$

However, Kuklinski's case did not end there. In 1995, the Polish Supreme Court reversed his death sentence on grounds of weak evidence, explicitly stating: "Proving the fact that Ryszard Kuklinski acted for the sovereignty and independence of the country inspired by his ideology, should influence his exculpation." 190 The case was thus referred back to the Military Prosecutor, who cancelled it on September 2, 1997, because Kuklinski had acted out of "higher necessity." 191 This is significant because at the time Kuklinski acted, he was directly aiding the enemy to a degree difficult to overstate. Nevertheless, he was exonerated on the basis that he had made his disclosures in pursuit of a higher goal; ${ }^{192}$ the outcome of the case is thus flatly at odds with the Israeli Supreme Court's decision in Vanunu and highlights the very different reactions that courts may take to similar arguments.

187. Dariusz G. Jonczyk, Colonel Ryszard Kuklinski and his Unique Mission: A Juxtaposition of the Post-Cold War Outlooks, at 7 (Jan. 1, 2010) (unpublished history dissertation, Northeastern University) (on file at Northeastern University).

188. Id. at $37-38$.

189. Id. at 46.

190. Rewizja Nadzwyczajna w sprawie płk Kuklińskiego (Extraordinary Revision of the Case of Colonel Kuklinski), 30 March 1995, Rzeczpospolita, 7 April 1995, 17, cited in translation in id. at 47 .

191. Id. at 47.

192. It is alleged that this decision was taken under pressure from the USA (apparently it was a precondition for Poland joining NATO). It is possible that some pressure was applied as American officials were very public in their desire to have Kuklinski legally exonerated at the time envisaged for Poland to join NATO. Id. at 171. However, this does not change the fact that Poland's Supreme Court authorized the possibility of exculpating breaches of state security on the grounds of acting out of higher necessity, even in cases of directly aiding the enemy. 


\section{Conflict of Duties-Matthew Diaz}

The basic argument used by Vanunu and Kuklinski was taken up, in a somewhat different variant, by Matthew Diaz, a Navy Judge Advocate stationed from 2004-05 at the detention facility in Guantanamo Bay (GTMO). In December 2004, GTMO received a request from Barbara Olshansky, a lawyer working for the Center for Constitutional Rights in New York, for information about the prisoners detained there. ${ }^{193}$ The request was ultimately rejected by GTMO's judge advocates in January $2005 .{ }^{194}$ Despite this decision, Diaz accessed the military computer systems and printed out the names and some details regarding the identity (for example, ethnicity and citizenship) of the detainees, as well as details regarding the interrogation team assigned to each detainee, all of which was considered to be classified information. He secretly mailed the information to Olshansky. ${ }^{195}$ When his actions were discovered, Diaz was charged with violating a general order, communicating classified information and removing classified material under Articles 92 and 134 of the Uniform Code of Military Justice (UCMJ). He was also charged under Article 133 of the UCMJ [Conduct Unbecoming an Officer and a Gentleman]. He was subsequently sentenced by court-martial to six months confinement and dismissal from the Navy. ${ }^{196}$

Diaz appealed his conviction to the U.S. Court of Appeals for the Armed Forces (CAAF), relying in his defence on an alleged conflict of duties within the domestic legal system. According to the CAAF judgement, these were:

on the one hand, his duty as a naval officer and an officer of the court to uphold the Constitution and the rulings of the Supreme Court and the district court in the habeas cases, and on the other hand, his duty as a Naval officer to maintain the confidentiality of information that his superiors should have authorized for release but did not. 197

While the CAAF did not agree that Diaz had a legal duty as an officer of the court to release the information, it agreed that ethical motives

193. United States v. Diaz, 69 M.J. 127, *5 (C.A.A.F. 2010).

194. Id.

195. Jessica Weisberg, Loosening Guantanamo's Grip: The Story of Matthew Diaz, NORTH AMERICAN CONGRESS ON LATIN AMERICA (Oct. 27, 2008), http://nacla.org/news/ loosening-guant $\% \mathrm{C} 3 \% \mathrm{~A} 1$ namos-grip-story-matthew-diaz.

196. Id.

197. United States v. Diaz, 69 M.J. 127, (C.A.A.F. 2010), at 22. 
could be relevant, in particular in relation to the charge under article 133 of the UCMJ, stating "[i]n our view, Appellant's general point is wellfounded." 198 A determination as to whether conduct is unbecoming of an officer and gentleman includes "taking all the circumstances into consideration." 199 The court found that "given Appellant's motive" his conduct was "not necessarily unbecoming or dishonorable. ... Evidence of honorable motive... is possible even where the conduct itself amounts to a delict." ${ }^{200}$ Nonetheless, the CAAF concluded that the lower court's error did not have a substantial influence on the findings, because it did not suffice to nullify the illegal action Diaz had committed. The CAAF here relied on Diaz's own knowledge that his action was illegal, as evidenced by his use of a "clandestine method of disclosure-by sending it through the postal system cut up in a Valentine's Day card;"201 that the regulations pertaining to classified information "and for addressing differences of legal views within the Department" demonstrate "that Appellant was not legally permitted to disregard the classified nature of the protected information"; and that the Supreme Court's ruling in Rasul did not indicate that it "intended its ruling to supersede in some manner counsel's other legal and ethical obligations." 202 Thus, while the CAAF found that Diaz did not have a legal duty to disclose the information, it admitted the theoretical possibility of such a duty existing in other circumstances and that motive could play a role in at least some delicts concerning the release of classified information. Furthermore, the Court explicitly stated that it is possible for conduct to be honourable even if it is illegal and that it was significant that Diaz acted furtively, not openly, in committing the actions in question.

While these three cases are not directly related to exposing violations of international law, they do contain some important seeds of thought regarding current cases. While the Israeli courts were adamant in their refusal to entertain Vanunu's motives, their American and European counterparts displayed approaches that were considerably more nuanced. In Diaz, the CAAF was willing to go so far as to admit that an action is not necessarily dishonourable even if it involves breaking the law and that it was certainly conceivable for the duty to withhold classified information to be judicially balanced against other duties. The Polish court went furthest of all, explicitly exonerating Kuklinski of unquestionably domestic crimes in the name of a higher necessity. Courts, even military

$\begin{array}{ll}\text { 198. } & \text { Id. at } 23 . \\ \text { 199. } & \text { Id. } \\ \text { 200. } & \text { Id. } \\ \text { 201. } & \text { Id. at } 25 . \\ \text { 202. } & \text { Id. }\end{array}$


courts, are thus far from closed off to the idea that a conflict of duties may exist in certain situations, even if the duty concerned is not explicitly laid down in domestic laws.

\section{Conflict of Duties/Higher Necessity under International Law-Gun, Kamm and Manning}

The whistleblowers involved in the three recent cases examined in this paper, all employed in security and defence-related capacities, continue the general lines of argument expressed above, but adapted to international law. Of the more recent cases, Gun's follows the tradition of pursuing the justification or exoneration of the whistleblower most closely. Although Gun was charged with disclosing damaging security information under Section 1 of the UK's Official Secrets Act of 1989, the case against her was eventually dropped because the prosecution chose not to offer evidence. ${ }^{203}$ Gun had planned to plead the defence of necessity, in this case the necessity of preventing loss to human life. ${ }^{204}$ That the prosecution dropped a case in which the accused had already confessed raises questions as to how successful they thought the defence of necessity would be, both in terms of legal effectiveness and in exposing the state to further international criticism for its international law violations.

Unlike Gun, Kamm significantly shifted her strategy during the course of legal proceedings against her. During her initial interrogation by Israeli intelligence agency Shin Bet, Kamm stated that the information she had released "should be public knowledge" and that "[w]hen I was burning the CDs I kept thinking that history tends to forgive people who expose war crimes." ${ }^{205}$ Later, however, she distanced herself from this stance and described her actions as merely "stupid" and "rash" without an overarching ideological purpose. ${ }^{206}$ Instead of attempting to fully exonerate herself, Kamm agreed to a plea bargain in which the charge of espionage while deliberately intending to harm state security, an offence

203. Davies, supra note 176. Martin Bright, The Woman Who Nearly Stopped the War, New STATESMAN (Mar. 19, 2008, 12:00 PM), http://www.newstatesman.com/blogs/ martin-bright/2008/03/katharine-gun-iraq-war-gchq.

204. Bright, supra note 203.

205. Luvitch, supra note 10.

206. See Paraszczuk, supra note 117; Naama Cohen-Friedman, "Kam Testimony Exposed" YNETNEws, 10.04.11, 8:15 AM), http://www.ynetnews.com/articles/0,7340, L-4130795,00.html; see also CrimA, 8445/11 Anat Kamm v. State of Israel PM 17959(01) 10, [2011] (Isr.), para. 17. 
which carries a maximum punishment of life imprisonment, was dropped, and Kamm admitted to possessing and passing on classified material, which carries a maximum sentence of fifteen years imprisonment. She was sentenced to four and a half years in prison, which she appealed to the Israeli Supreme Court. ${ }^{207}$ None of the courts in which Kamm's case was heard found the renunciation of her original statements credible. All decisions therefore started from the position that she had indeed passed the documents to Blau due to a desire to expose war crimes. ${ }^{208}$

Starting out from this point, Justice Arbel, delivering the Supreme Court's decision took a very similar stance to the Court's findings twenty years earlier in Vanunu. In particular, she declared that the court had a duty to punish those who broke rules to fix the world according to their own ideas of right and wrong. ${ }^{209}$ However, in his separate but concurring opinion, Judge Meltzer stated that he would be in favour of reducing sentences when a crime was committed for altruistic purposes, just as crimes committed for particularly nefarious motives were often punished with stiffer sentences. ${ }^{210}$

Notwithstanding Justice Arbel's uncompromising stance on ideology, she voted in favour of reducing Kamm's sentence due, inter alia, to the fact that she had already been placed under house arrest for a lengthy period of time during her trial, and what Arbel considered to be her extrajudicial punishment, namely the social stigma attached to revealing information which could compromise Israel's security. ${ }^{211}$ Kamm's sentence was commuted to three and a half years. ${ }^{212}$

It is extremely doubtful whether Kamm's sentence would have been lowered had she passed on the documents for any malicious purpose, such as direct material gain, her own self-aggrandizement, or harming the public reputation of the military personnel implicated in the documents. In the Supreme Court, her case was compared to two others where the defendants had acted out of carelessness rather than maliciousness. ${ }^{213}$

207. Joanna Paraszczuk, Supreme Court Hears Kamm's Sentencing Appeal, Jerusalem Post, July 31, 2012, at 5; Peled, supra note 9; Edelman, Closed Door Trial, supra note 176.

208. CrimA, 8445/11 Anat Kamm v. State of Israel PM 17959(01) 10, [2011] (Isr.), para. 2, 17 (referring to the Tel Aviv District Court), para. 2 (and to its own assessment).

209. Id. 96

210. Id. at $18, \Phi 2$.

211. Id. ๆ 19.

212. Paraszczuk, supra note 117; Edelmann, Closed Door Trial, supra note 176; Paraszczuk, Sentencing Appeal, supra note 207; Aviel Magnezi, Court Cuts Anat Kam's Prison Sentence, YNET NEws (Dec. 31, 2012, 10:11 AM), http://www.ynetnews.com/ articles/0,7340,L-4326565,00.html.

213. CrimA, 8445/11 Anat Kamm v. State of Israel PM 17959(01) 10, [2011] (Isr.), ๆๆ 13-14. 
While remaining firm on the point that ideological motivations cannot lead to acquittal, such impetuses apparently can, in the opinion of some judges, be taken into consideration when sentencing.

Similar to Kamm, during Private Manning's trial, the defence chose to portray Manning as young and naïve, insinuating that leaking the documents had been synonymous with exercising poor judgment coupled with good intentions. ${ }^{214}$ Manning herself apologized at her sentencing hearings stating, "I am sorry that my actions hurt people. I'm sorry that they hurt the United States," and admitting, "I should have worked more aggressively inside the system." ${ }^{215}$ However, this was somewhat at odds with her statement regarding the documents made during trial: "I felt I had accomplished something that allowed me to have a clear conscience based upon what I had seen." ${ }^{216}$ Regarding the Iraqi dissidents whose probable torture she had previously objected to, Manning stated:

I knew if I continued to assist the Baghdad Federal Police in identifying the political opponents of Prime Minister al-Maliki, those people would be arrested and in the custody of the Special Unit of the Baghdad Federal Police and very likely tortured and not seen again for a very long time-if ever. ... Instead of assisting the Special Unit of the Baghdad Federal Police, I decided to take the information and expose it to the WLO [Wikileaks Organization], before the upcoming 7 March 2010 election, hoping they could generate some immediate press on the issue and prevent this unit of the Federal Police from continuing to crack down on political opponents of al-Maliki.217

This seems to be an attempt at justifying those actions, although, unlike Gun and Kamm, Manning did not directly appeal to international law as a possible justification, despite its obvious relevance for the case at hand. Manning was sentenced to thirty-five years in prison ${ }^{218}$ after being

214. See Transcript of Closing Arguments, supra note 98, at 67.

215. Courtney Kube, Matthew DeLuca \& Erin McClam, 'I'm sorry that I hurt the United States': Bradley Manning Apologizes in Court, NBC News (Aug. 15, 2013, 4:07 PM), http://usnews.nbcnews.com/_news/2013/08/14/20020933-im-sorry-that-i-hurt-theunited-states-bradley-manning-apologizes-in-court?lite.

216. See Bradley Manning's Personal Statement to Court Martial: Full Text, THE GUARDIAN (Mar. 1 2013, 5:58 PM), http://www.theguardian.com/world/2013/mar/01/ bradley-manning-wikileaks-statement-full-text.

217. Id.

218. It is believed that she could be paroled in as little as 8 years, as time served, as well as an additional 120 days for harsh treatment, is deducted. See Savage \& Huetteman, supra note 7 . 
convicted of multiple counts of theft, espionage, and computer fraud. She is currently appealing. ${ }^{219}$

These cases show that courts and governments are, subject to jurisdiction, while far from lenient, also not quite as condemnatory of external whistleblowing on international law violations as is often perceived, despite the complications raised by determining when an international law violation has been committed and the dualist nature of most domestic legal systems. Both Kamm and Manning received relatively light sentences and Gun's case was dropped completely. Additionally, the cases of Guja, Kuklinski, Diaz, and Kamm demonstrate that courts are not completely closed off to arguments of higher necessity, or the possibility of a conflict of duties (be they with natural law or international law), even in cases where sensitive information is exposed. Nevertheless, whistleblowers who are motivated to speak out against violations of international law are often left without adequate protection, even in cases where states have incorporated the international laws in question into their own domestic systems. An international legal apparatus that relies on individuals to expose serious breaches of its norms should be taking a stronger stance on protecting anyone actually willing to do so. National courts have already made some modest headway in this regard and other tentative steps seem to be forthcoming.

\section{FUTURE CONSIDERATIONS}

History has shown that all states have secrets and that some of these secrets relate to their own violations of international law, violations which those states may perceive as important, or even necessary, to give them an advantage within the international community or even to protect their citizens or their future existence. Moreover, the most powerful states operate intelligence services and surveillance programs which put them in a fairly good position to know about the international law violations committed by other states, ${ }^{220}$ revelations which may or may not be useful to make public. In the short-term, many states thus only

219. Savage, supra note 176; Wikileaks Source Manning Convicted on Most Charges, supra note 176.

220. For example, the fact that the NSA was spying on civilians and other governments seems to have been well-known at least within other secret services. Paul Hamilos, Spain Colluded in NSA Spying on its Citizens, Spanish Newspaper Reports, THE GUARDIAN (Oct. 30, 2013, 7:41 AM), http://www.theguardian.com/world/2013/ oct/30/spain-colluded-nsa-spying-citizens-spanish-el-mundo-us; Adam Entous \& Siobhan Gorman, Europeans Shared Spy Data with US, WALL ST. J., Oct. 30, 2013, at A1; NSA Asked Japan to Tap Region-wide Fiber Optic Cables in 2011, THE JAPAN TIMES (Oct. 27, 2013), http://www.japantimes.co.jp/news/2013/10/27/world/nsa-asked-japan-to-tapregionwide-fiber-optic-cables-in-2011/. 
have a functional interest in whistleblowing when the whistle is being blown on someone else to their advantage. They do not have an immediately obvious interest in the double-edged sword that protecting whistleblowing in general represents.

Nonetheless, many actors do stand to benefit from better whistleblower protection. For example, states that are largely international law compliant; the citizens of states that have ratified treaties and who have an interest in knowing how their own state and other states are performing in relation to treaty compliance; and citizens of democratic nations who need to make sound decisions based on complete information.

Furthermore, while states may, in many respects, be guilty of hypocrisy, they have nonetheless exhibited a profound proclivity for binding themselves to more exacting standards of conduct. Indeed, the entire project of international law over the past century represents an enormous modification of human and state behaviour. This article therefore argues that states, and more importantly, their citizens, are generally committed to observing international law, and that the hypocrisy and lapses we observe, grievous though they are, represent the challenges, setbacks, and shortcomings on that path. Whistleblowing is an important tool in ensuring that such setbacks are as short-lived as possible and the importance of this tool for international law is gaining increased recognition, particularly in Europe.

The increased value of the role of whistleblowers in international law enforcement is buttressed by legislation in some European jurisdictions which lays a domestic duty on the individual to inform of certain international law violations. For example, under Section 138 of the German Criminal Code, any person who acquires knowledge that a war of aggression is being prepared for or that genocide, crimes against humanity, or war crimes will be perpetrated, could face up to five years in prison if he does not share his knowledge with the authorities in a timely fashion. ${ }^{221}$ To be sure, such legislation authorizes reporting to "the authorities" only, not to the general public, but it nonetheless escalates the pressure on the potential whistleblower and exposes them to a situation where to err on the side of exposure becomes ever more likely. In a system where withholding knowledge that could prevent grave international law breaches is punishable, it is unsurprising that citizens perceive a duty to

221. Strafgesetzbuch [StGB] [Penal Code], 1976, Bundesgesetzblatt [BGB1.] 18/989, as amended, § 138, paras. 1, 5 (Ger.). 
share their information, including with the public, if necessary. Indeed, under this legislation, Manning, Kamm, and Gun, would all possibly have made themselves punishable had they failed to share their information with the relevant authorities. To tell citizens that they must - under threat of incarceration - tell authorities of these pending international law violations, but that, should this prove futile, they should continue to withhold information from the public, is both confusing and illogical as it obviates the teleological purpose of the law.

This increase in legislation is coupled with increasingly open attitudes in general towards the role whistleblowers can play in domestic law enforcement. Indeed, some European States reward whistleblowers for exposing private violations of their domestic laws, even in cases where the whistleblower thereby breaks foreign domestic laws, becoming, in some cases, an accomplice to these crimes. In 2006, the German Federal Ministry of Finance paid bank computer technician Heinrich Kieber 4.2 million Euros for DVDs which provided evidence that hundreds of wealthy Germans had been evading taxes by availing themselves of bank services in Liechtenstein. ${ }^{222}$ The German state of Rheinland-Pfalz also purchased information from whistleblowers working in Swiss banks. ${ }^{223}$ Similarly, when an HSBC Private Bank employee who had disseminated information on tax avoidant clients was apprehended in Spain, the Spanish National Court ruled that his disclosure was protected since he revealed criminal activity. ${ }^{224}$ This is mirrored in the United States by Section 922 of the Dodd-Frank Wall Street Reform and Consumer Protection Act, which foresees substantial rewards for anyone who reveals evidence of securities and commodities law violations. ${ }^{225}$

While such whistleblowers aid domestic law enforcement, not international law enforcement, these examples do seem to indicate an increased awareness that in cases of widespread breaches, whistleblowing becomes essential to law enforcement. To apply this to international law violations then becomes less of a leap, one which the European Parliament already seems prepared to make, having recently stressed the need for

222. Lynneley Browning, "Banking Scandal Unfolds Like a Thriller" N.Y. TIMES, Aug. 15, 2008, at C8; Liechtenstein: BND-Informant hat Todesangst, DER SPIEGEL, Mar. 10, 2008, at 21; Beat Balzli, Matthias Bartsch, Dirk Kurbjuweit, Conny Neumann, Barbara Schmid \& Holger Stark, Ein braver Sohn, DER SPIEGEL (Feb. 25 2008), http://www.spiegel. de/spiegel/print/d-55946114.html.

223. Giles Broom, Julius Baer Worker Jailed for Three Years for Breaking Secrecy, BlOOMBERG News (Aug. 22, 2013), http://www.businessweek.com/news/2013-08-22/ julius-baer-worker-jailed-for-three-years-for-breaking-secrecy.

224. Id.

225. Dodd-Frank Wall Street Reform and Consumer Protection Act, Pub. L. No. 111-203, 124 Stat. 1376 (2010). 
"procedures allowing whistleblowers to unveil serious violations of fundamental rights" and the importance of providing such people with the protection they need, including at international level.226 While the international custom of granting political asylum can be utilized in some cases - Edward Snowden in particular has thus far used the application of asylum and extradition rules to his advantage in Russia ${ }^{227}$ - this solution presupposes the whistleblower's ability to travel to a third country before their actions are discovered. Thus, its suitability as a vehicle for whistleblower protection is limited. When the European Parliament calls for increased whistleblower protection on an international level, it presumably means something more than using the existing asylum regime to one's advantage.

Among the jurisdictions under consideration in this paper, European legal systems clearly take the most benevolent stance on external security-industry whistleblowers. In Europe, such whistleblowers are least likely to face prosecution (as with Gun) and most likely to have their case considered within the greater scheme of the legal system's protected values when they do (as with Kuklinski and the civilian case, Guja). Moreover, as the statements by European Parliament indicate, there seems to be an increasing awareness within Europe that those who reveal serious breaches of law, including international law, must be protected. Such considerations are, of course, in their infancy and are, as indicated in this paper, shared only partially by the USA and Israel. Nonetheless, they represent an important avenue for future international law enforcement to explore.

\section{CONCLUSIONS}

External whistleblowing is an effective method of international law enforcement; indeed, it is necessary in the worst cases where international law violations attain systemic dimensions. At the same time, however, those individuals who take the step of external whistleblowing in such circumstances are often left facing strict domestic penalties for their actions without adequate legal protection. There are, of course, serious challenges to any regime of protection for international law whistleblowers, such as the level of certainty they should be expected to possess that an international law breach has been committed, and the dualist nature of

226. Press Release, European Parliament, supra note 49.

227. See Vladimir Radyuhin, Snowden Contacted Us from Hong Kong for Asylum: Putin, The Hindu, Sept. 5, 2013. 
most domestic legal systems vis-à-vis international law which makes defences grounded in international law problematic. These challenges are, however, manageable and any whistleblower protection can be granted under strict conditions, such as the impracticality of internal whistleblowing in the concrete scenario, an appropriate knowledge bar to prevent grossly inaccurate claims of violations, or even the demand that the information is released in such a way that it does not harm national security in any provable manner. Both courts and legislative bodies appear to recognize the importance of closing this gap in whistleblower protection, especially in Europe where the value of external whistleblowing for international law enforcement is finding increasing traction. 